\title{
Molecular data reveal hidden diversity in the central Andean species Weberbauera spathulifolia (Thelypodieae: Brassicaceae)
}

\author{
DIEGO L. SALARIATO ${ }^{1, *, \bullet, ~ H U B E R ~ T R I N I D A D ~}{ }^{2}$, ASUNCIÓN CANO $^{2,3}$, \\ FERNANDO O. ZULOAGA ${ }^{1}$ and IHSAN A. AL-SHEHBAZ ${ }^{4}$ \\ ${ }^{1}$ Instituto de Botánica Darwinion (CONICET-ANCEFN), Labardén 200, Casilla de Correo 22, \\ B1642HYD, San Isidro, Buenos Aires, Argentina \\ ${ }^{2}$ Laboratorio de Florística, Departamento de Dicotiledóneas, Museo de Historia Natural, Universidad \\ Nacional Mayor de San Marcos (UNMSM), Avenue Arenales 1256, Lima 11, Peru \\ ${ }^{3}$ Instituto de Investigación de Ciencias Biológicas Antonio Raimondi (ICBAR), Facultad de Ciencias \\ Biológicas, (UNMSM), Calle Germán Amezaga 375, Lima 1, Peru \\ ${ }^{4}$ Missouri Botanical Garden, 4344 Shaw Boulevard, St. Louis, Missouri 63110, USA
}

Received 28 June 2019; revised 13 December 2019; accepted for publication 26 March 2020

\begin{abstract}
Weberbauera (Brassicaceae, tribe Thelypodieae) comprises 18 species distributed along the central Andes of Argentina, Bolivia, Chile and Peru. Of these species, W. spathulifolia has the largest geographical range in the genus, extending $c$. $3000 \mathrm{~km}$ along the Andean highlands from La Rioja Province in Argentina to Ancash Department in Peru. This species also shows the greatest morphological variation in the genus. However, whether this geographical and morphological variation represents one or more lineages remains unclear. In this study, we analyse W. spathulifolia across its entire distribution range using molecular, morphological and ecological data. Because there is no phylogenetic analysis for the genus, we generated a comprehensive molecular sampling using nuclear (ITS) and plastid (trnL-F and trnH$p s b A$ ) sequences for other Weberbauera spp. and representatives of South American Thelypodieae. Results support the presence of two different lineages within W. spathulifolia, one in the northern part of the species range and the other distributed across its southern and central range. In addition to the morphological differences and the allopatric distribution, these lineages also differ in their climatic niches. Therefore, we propose here to retain the northern lineage under W. spathulifolia and to treat the southern-central lineage under W. orophila, comb. nov. Phylogenetic placement of Weberbauera spp. among the South American Thelypodieae is also analysed and discussed. Results of this study contribute to understanding the biodiversity and evolution of the Andean Brassicaceae.
\end{abstract}

ADDITIONAL KEYWORDS: Central Andes - Cruciferae - molecular phylogenetics - South America.

\section{INTRODUCTION}

Extending for nearly $9000 \mathrm{~km}$, Andean South America is one of the most important alpine ecosystems in the world, and one of the most diverse areas on Earth in terms of plant species (Barthlott et al., 2005). In particular, the tropical Andes (Andes from Venezuela to northern Argentina and Chile) are the most

*Corresponding author. E-mail: dsalariato@darwin.edu.ar [ORCID IDs Diego L. Salariato: 0000-0002-3253-3755; Asunción Cano: 0000-0002-5759-4650; Ihsan A. Al-Shehbaz: 0000-0003-1822-4005] species-rich region on Earth, with endemics of this region comprising c. $6.7 \%$ of all plant species worldwide (Myers et al., 2000). Different geological and climatic factors have influenced species richness of this region through speciation, dispersal and extinction of lineages (Antonelli et al., 2018), resulting in the accumulation of this unparalleled diversity. Mountains can act as cradles, bridges, barriers and reservoirs or museums (Perrigo, Hoorn \& Antonelli, 2019), and the interaction between climate and mountains produces a high environmental heterogeneity that can lead to high species diversity (Antonelli et al., 2018; Perrigo et al., 2019). 
Brassicaceae (the mustard family) are well represented in South America, with c. 405 native species mainly distributed along the Andes. These species inhabit a variety of different environments along the biogeographical provinces of North Andean Paramo, Puna, Prepuna, Altoandina, Yungas and Subandean Patagonia (Cabrera \& Willink, 1973; Morrone, 2001). These regions, with the Atacama-Sechura desert, the Chilean Matorral and the Patagonian Steppe, provide a high diversity of habitats for the diversification of numerous plant groups (Luebert \& Weigend, 2014), including several lineages of this family (Salariato et al., 2016). Moreover, new species continue to be described for the Andes (e.g. Al-Shehbaz et al., 2018; Salariato, Zuloaga \& Al-Shehbaz, 2019), which seems to indicate that biodiversity of the family is still underestimated for the region. The alpine ecosystems are considered highly sensitive to climatic changes because their distribution has been closely linked to temperature and precipitation patterns (Halloy \& Mark, 2003; Sklenář \& Balslev, 2005; Cuesta et al., 2017). Climatic changes and habitat loss can have an impact on different biodiversity components and biome integrity (Dawson et al., 2011; Bellard et al., 2012; Mantyka-Pringle et al., 2015; Urban, 2015). Therefore, one of the most crucial issues for any conservation initiative (e.g. categorization of species on the IUCN Red List of Threatened Species) is the study of systematics and biodiversity of Andean taxa and the identification of new species and evolutionarily significant units (Moritz, 1994).

Among the Andean members of Brassicaceae, Weberbauera Gilg \& Muschl. comprises 18 species distributed along the central Andes of Argentina, Bolivia, Chile and Peru (c. $7 \mathrm{~S}^{\circ}-29 \mathrm{~S}^{\circ}$ latitude) at elevations of 3600-5000 m (Al-Shehbaz, 1990, 2004; Salariato, Al-Shehbaz \& Zuloaga, 2018). This genus, included in tribe Thelypodieae (Al-Shehbaz, 2012), is comprised of perennial herbs [except for $W$. peruviana (DC.) Al-Shehbaz], with woody (simple or branched) caudices, rosulate basal leaves, siliques and incumbent cotyledons (Al-Shehbaz, 1990). However, there are no synapomorphies supporting the genus, which would suggest the potential non-monophyly of the group given the high levels of morphological homoplasy exhibited in the family (Huang et al., 2016). This consideration was recently reflected in the work of Salariato et al. (2018); these authors, based on evidence from molecular phylogenetic analyses, transferred several Weberbauera spp. to Stenodraba O.E.Schulz in tribe Eudemeae, demonstrating that this distinctive morphology can be observed in other nonrelated South American lineages. Species currently included in Weberbauera grow along the Altoandina and Puna biogeographical provinces of Cabrera \&
Willink (1973) on a variety of different microhabitats. Of these, 12 species (c. 66\%) are represented by fewer than five collections, whereas W. spathulifolia (A.Gray) O.E.Schulz, W. peruviana (DC.) Al-Shehbaz and W. herzogii (O.E.Schulz) Al-Shehbaz are the most abundant.

Weberbauera spathulifolia has the largest geographical range in the genus (Fig. 1), extending $c$. $3000 \mathrm{~km}$ along the Andean highlands from La Rioja Province in Argentina $\left(29^{\circ} \mathrm{S}\right.$ latitude) to Ancash Department in Peru ( $8^{\circ} \mathrm{S}$ latitude). This species also shows the greatest morphological variation in the genus and has been cited as one of the most variable South American Brassicaceae (Al-Shehbaz, 1990). This variation is most noticeable in length of infructescences, occurrence of bracts, type and density of trichomes and shape and margin of leaves (Al-Shehbaz, 1990). However, how this variation is associated with the genetic structure and the geography of the species remains unclear. In this study, we analyse the identity of W. spathulifolia across its entire distribution range using molecular, morphological and ecological data. Because there is no phylogenetic analysis for the genus, we generated a comprehensive molecular sampling using nuclear (ITS) and plastid ( $\operatorname{trn} L-F$ and trnH-psbA) sequences for most Weberbauera spp. and other representatives of South American Thelypodieae. We first analyse the molecular data to detect different lineages within W. spathulifolia, using phylogenetic and coalescent models, and then characterize them according to their morphological variation, geographical ranges and climatic niches represented both along the environmental (E) and geographical (G) spaces. Phylogenetic placement of Weberbauera spp. among South American Thelypodieae is also analysed and discussed. Results of this study contribute to our understanding of the biodiversity and evolution of the Andean Brassicaceae.

\section{MATERIAL AND METHODS}

\section{TAXON SAMPLING AND MOLECULAR DATASET}

For the molecular analyses, we sampled 12 accessions of W. spathulifolia, representing major geographical areas and covering morphological variation, and 32 accessions of another ten species of the genus (c. $61 \%$ of the genus) (Fig. 1; Appendix 1). Because the monophyly of Weberbauera has not been tested and phylogenetic placement of South American Thelypodieae is poorly understood due to the lack of resolution of molecular phylogenetic trees (Warwick et al., 2009, Salariato \& Al-Shehbaz, 2014), we also included 45 additional accessions representing 31 species and ten genera from South American Thelypodieae and 23 accessions 


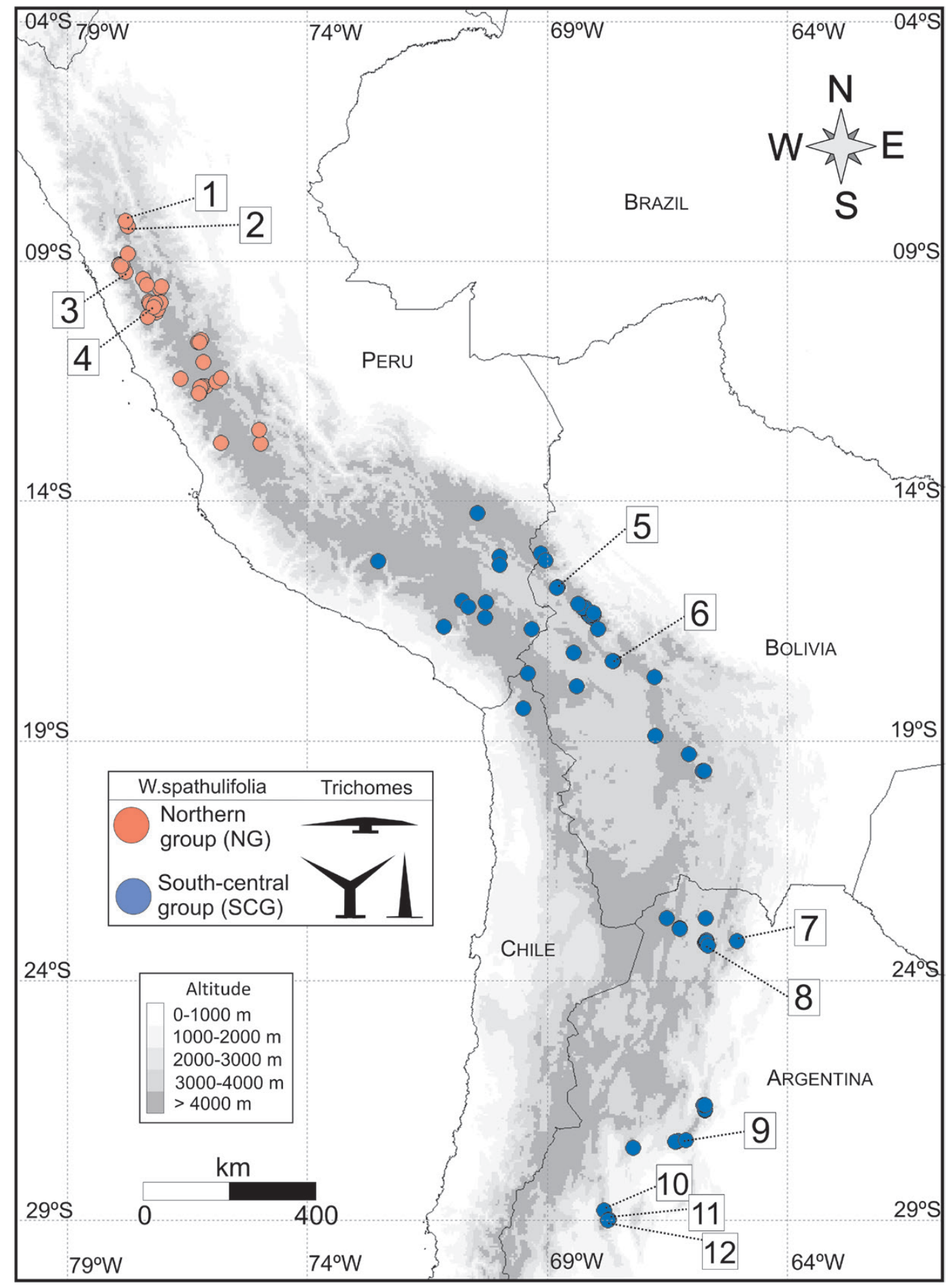

Figure 1. Distribution map of Weberbauera spathulifolia. Red and blue dots represent specimens of the northern group (NG) and the southern-central group (SCG), respectively. Numbers associated with dots indicate specimens used in the phylogenetic analyses (see Appendix 1).

of 22 North and Central American species of the tribe. Phylogenetic analyses were conducted using ITS (nrDNA), trnL-F and trnH-psbA (plastid DNA) sequences. Protocols for extraction, amplification and DNA sequencing are described in Salariato, Al-Shehbaz \& Zuloaga (2018). In total, 153 new 
sequences were generated and submitted to GenBank (Appendix 1) (https://www.ncbi.nlm.nih.gov/genbank/). Sequences were assembled and edited using the program Chromas Pro v.1.7.7 (Technelysium Pty Ltd, Brisbane, Australia), which was also used for checking the presence of single peaks in the chromatograms, especially for the ITS sequences. Alignments were generated with MUSCLE v.3.8.31 (Edgar, 2004) using a first round of multiple alignments and posterior rounds of refinement under the default settings. The alignments obtained were then checked and improved manually where necessary using Bioedit v.7.2.5 (Hall, 1999). Aligned matrices and all other supplemental data are available from the Supporting Information, TreeBASE (http://purl.org/phylo/treebase/phylows/ study/TB2:S24633) and figshare (Salariato, 2019).

\section{PhylOGENETIC ANALYSES}

To assess the species boundaries of W. spathulifolia, we used ITS, trnL-F and trnH-psbA sequences from the Weberbauera accessions and the datasets for tribe Thelypodieae (alignments are available online in the Supporting Information, TreeBASE (http://purl. org/phylo/treebase/phylows/study/TB2:S24633) and Salariato (2019). First, individual and concatenated datasets (plastid DNA and ITS+plastid DNA) were analysed using maximum likelihood (ML) and Bayesian inference (BI). In these analyses, gaps were treated as missing data and Sisymbrium orientale L. (tribe Sisymbrieae) was included as the outgroup. Bestfit models of nucleotide evolution were identified using the Akaike information criterion (AIC) implemented in jModeltest2 v.2.1.6 (Darriba et al., 2012): TIM3+I+G (ITS) and TPM1uf+G (trnL-F and $\operatorname{trn} H-p s b A)$. The ML analyses were conducted in RAxML v.8.2.10 (Stamatakis, 2014) using non-parametric bootstrap (BS) analysis and searches for the best-scoring ML tree in a single run (Stamatakis, Hoover \& Rougemont, 2008). We performed 1000 rapid bootstrap inferences and a thorough ML search under the GTRGAMMAI (ITS) and the GTRGAMMA ( $t r n L-F$ and $t r n H-p s b A$ ) models. Bayesian analyses were conducted using MrBayes v.3.2.6 (Ronquist et al., 2012) setting the number of substitution types to 'mixed' (which results in the Markov chain sampling over the space of all possible reversible substitution models), and rates $=$ invgamma (ITS) or gamma ( $t r n L-F$ and $\operatorname{trn} H$ - $p s b A$ ). Two simultaneous analyses, starting from different random trees and with four Markov Monte Carlo chains, were run for 40 million generations, sampling every 10000 generations to ensure independence of the successive samples. The convergence and effective sample size (ESS) were checked with the average standard deviation of split frequencies (ASDSF) <
0.01 , the potential scale reduction factor $(\mathrm{PSRF}) \sim 1$ and the ESS for all parameters $>200$. The first 1000 trees ( $25 \%$ of total trees) were discarded as burn-in, and the remaining samples of each run were combined and used to calculate the $50 \%$ majority-rule consensus tree and the maximum clade credibility (MCC) tree, the latter was estimated using TreeAnnotator v.1.8.4 (http://beast.community/treeannotator). Trees obtained in ML and BI analyses are available from Salariato (2019). All RAxML and MrBayes analyses were conducted in the CIPRES Science Gateway v.3.3 (http://www.phylo.org/) (Miller, Pfeiffer \& Schwartz, 2010).

To address levels of discordance among nuclear ribosomal (ITS) and plastid ( $\operatorname{trn} L-F$ and $\operatorname{trn} H$-psbA) trees and their influence on the concatenated analyses, congruence among partitions was assessed using a Bayesian concordance analysis (Ané et al., 2007; Baum, 2007) implemented in the software BUCKy v.1.4.4 (Larget et al., 2010). The BUCKy analysis was conducted using the posterior distribution of the ITS and plastid DNA trees produced with MrBayes, with two runs, four chains and one million generations following a burn-in of 100000 (10\%); the discordance parameter $(\alpha)$, which represents the a priori expected level of discordance, was set to 1,10 and 100 . In addition to the concatenated and concordance analyses, incongruences between ITS and plastid DNA data were also visualized in a filtered supernetwork calculated with SplitsTree v.4.14.18 (Huson \& Bryant, 2006) using the Z-closure algorithm (Huson et al., 2004), 1000 Bayesian posterior trees of each nuclear and plastid dataset and filtering the splits to show only those present in a minimum of $30 \%$ input trees.

Because specimens of W. spathulifolia were included in two different clades, a post hoc topological test was carried out to rule out the possibility of monophyly for the species across its distribution range. For this purpose, we used the SH test (Shimodaira \& Hasegawa, 1999) and the approximately unbiased test (AU) (Shimodaira, 2002). Searches of constrained topologies, in which specimens of W. spathulifolia were forced to be monophyletic, were conducted in RAxML with 1000 replicates and the models used above. Site-wise log-likelihoods of all hypotheses were first calculated with PAUP v.4.0b10 (Swofford, 2002) and then used in CONSEL v.0.1j (Shimodaira \& Hasegawa, 2001 ) to estimate $P$-values of the $\mathrm{SH}$ and AU tests, rejecting the hypothesis when $P<0.05$. Additionally, we also compared the hypothesis of monophyly using Bayes-factor (BF) analysis. For this, BF was calculated in MrBayes using marginal likelihood estimations (MLE) obtained via the stepping-stone sampling method (SS; Xie et al., 2011). We conducted 
the stepping-stone sampling using two independent runs of four Markov chains, with $\alpha=0.4$, taking 50 steps for a total of 39780000 generations, sampling every 10000 generation and discarding the first 780 000 generations as burn-in (the same length as each step). The contribution to the marginal likelihood in each step was estimated from a sample size of 78 . The $2 \operatorname{lnBF}$ was calculated from the MLE to compare the different hypotheses (monophyly vs. non-monophyly of W. spathulifolia) following criteria of Kass \& Raftery (1995): $2 \ln B F=0-2$ 'not worth more than a bare mention', $2 \operatorname{lnBF}=2-6$ 'positive' support, $2 \operatorname{lnBF}=6-10$ 'strong' support and $2 \mathrm{lnBF}>10$ 'decisive' support in distinguishing between competing hypotheses.

Alternatively, assuming that discordance could be caused by incomplete lineage sorting, we conducted species-tree analysis under the multispecies coalescent model implemented in *BEAST extension (Heled \& Drummond, 2010) of BEAST v.1.8.4 (Drummond et al., 2012). We first performed analyses using all accessions as separate OTUs in the species tree to compare with results obtained from the concatenated analyses. Then, we conducted a Bayes-factor delimitation (BFD) approach (Grummer, Bryson \& Reeder, 2014) to test among two alternative hypotheses: (1) all individuals of $W$. spathulifolia represent the same species; and (2) specimens currently included under W. spathulifolia represent two different species, according to the lineages recovered in the phylogenetic analyses (clades NG and SCG, see Results). Nucleotide substitution models selected by the AIC in jModeltest2, an uncorrelated lognormal clock model (UCLN), a birth-death process for the species-tree prior and the piecewise linear with constant root for the population size model were assigned to each sampled locus. Four runs were conducted in BEAST using 100 million generations and sampling every 10 000. Convergence and ESS was checked in Tracer v.1.7.1 (Rambaut et al., 2018), and the first 25\% of each run was discarded as burn-in. Replicates were combined using LogCombiner v.1.8.4 (http:// beast.community/logcombiner), and the species maximum clade credibility tree was calculated using TreeAnnotator v.1.8.4 (http://beast.community/ treeannotator). For hypothesis testing in the BFD approach, BF was calculated using MLE obtained both by path sampling (PS; Lartillot \& Philippe, 2006) and stepping-stone sampling methods (Xie et al., 2011 ) with 100 steps of five million generations each and $\alpha=0.3$. All *BEAST analyses were conducted in the CIPRES Science Gateway v.3.3 (www.phylo. org; Miller, Pfeiffer \& Schwartz, 2010). XML files for species delimitation analyses in BEAST and the trees obtained are available from Salariato (2019).

\section{MORPHOLOGICAL STUDIES}

Morphological studies in W. spathulifolia were based on herbarium specimens mainly from BAA, CONC, CORD, LPB, LIL, SI and USM (acronyms follow Thiers, 2019) and on fresh material collected during field trips in the Andes of Argentina, Bolivia and Peru (see Taxonomic Treatment for vouchers). Specimens examined covered the entire geographical range and morphological variation. We further analysed most variable characters reported by Al-Shehbaz (1990): shape and margin of leaves; type and density of trichomes on leaves and stems; occurrence of bracts and lengths of the infructescence, fruit and style. Trichomes were examined using a Philips XL series 30 scanning electron microscope, operating at 10-15 $\mathrm{kV}$ at the Museum of Natural Sciences 'Bernardino Rivadavia', for which leaves and stems were previously cleaned with xylene, subjected to sonication for 5 min, dried at room temperature for $12 \mathrm{~h}$, mounted on aluminium stubs and coated with gold : palladium (40 :60).

\section{ECOLOGICAL NICHE COMPARISONS}

Because both molecular and morphological data supported the presence of two different lineages within W. spathulifolia: the northern group (NG) and the southern-central group (SCG) (see Results), we analysed and compared their geographical and climatic-niche ranges. For niche comparisons in the geographical and environment spaces, we used species occurrences obtained from the examination of specimens deposited in different herbaria and used in the morphological analyses (for complete vouchers, see Taxonomic Treatment). All records were mapped using QGIS v.2.18.12 'Las Palmas' (Quantum GIS Development Team, 2016) for visual inspection. In cases of specimens with no GPS coordinates but exact locality names, records were georeferenced using Google Earth Pro v.7.3.2.5776 (https://www.google.com.ar/intl/ en/earth/). After removing duplicates and occurrences closer to 30 arc-seconds (c. $1 \mathrm{~km})$, we obtained 102 data points $(\mathrm{NG}=41, \mathrm{SCG}=61)$ (dataset available in Table S1 of Supporting Information and in Salariato, 2019). Information on the current climatic conditions within the study area was extracted from the recently developed CHELSA 1.2 climatic dataset (Karger et al., $2017 \mathrm{a}, \mathrm{b})$ at a resolution of 30 arc-seconds $\left(c .1 \mathrm{~km}^{2}\right)$. CHELSA data is suitable for studies in mountain areas because they incorporate orographical predictors such as wind field and valley exposition, increasing accuracy of species range prediction, principally for the precipitation pattern (Karger et al., 2017a). Values of all 19 bioclimatic variables were extracted from the area defined by a minimum convex polygon 
enclosing all specimen records with $50-\mathrm{km}$ buffer zone (c. $07^{\circ} 31^{\prime} \mathrm{S}-29^{\circ} 25^{\prime} \mathrm{S}$ latitude, $78^{\circ} 20^{\prime} \mathrm{W}-65^{\circ} 55^{\prime} \mathrm{W}$ longitude; see also Supporting Information, Fig. S1). Additionally, we also included data from the annual aridity index (AI) and potential evapotranspiration (PET) from the CGIARCS database 2 (Trabucco \& Zomer, 2019) at the same resolution. Data extraction and manipulation were done using the packages adehabitatHR v.0.4.16 (Calenge, 2006), raster v.2.8.19 (Hijmans, 2019), sp v.1.3.1 (Bivand, Pebesma \& Gomez-Rubio, 2013) and maptools v.0.9.5 (Bivand \& Lewin-Koh, 2019), implemented in R v.3.5.2 (R Core Team, 2018).

Niche comparisons among groups within W. spathulata in the environmental (E) space were estimated using the PCA-env approach of Broennimann et al. (2012), in which a principal component analysis (based on a correlation matrix) is calibrated on the entire environmental space (in our case, 19 bioclimatic variables from CHELSA+IA+PET) included in the study area (the $50 \mathrm{~km}$-buffered minimum convex polygon enclosing all specimen occurrences for this work, Fig. S1). We considered the first three principal components (PC), which accounted for $87.75 \%$ of the niche variation (see Results). First, as a preliminary approximation, we conducted a Wilcoxon rank sum test to assess for differences between the NG and the SCG for PC1, $\mathrm{PC} 2$ and $\mathrm{PC} 3$. Then, we divided this environmental space in a grid of $100 \times 100$ cells, in which each cell corresponds to a unique vector of the available environmental conditions in the study area. Because the number of species occurrences can be biased, resulting in an under- or over-estimation of the species density, a kernel-density function is applied for smoothing the density of occurrences for each of the cells in the environmental space (see Broennimann et al., 2012 for details on the methodology and the kernel-density estimator). The density grids for each species were used subsequently to compute the niche overlap by means of the Schoener's $D$ statistic (Schoener, 1970; reviewed in Warren, Glor \& Turelli, 2008), which ranges from 0 (no overlap) to 1 (complete overlap). Equivalency between niches of the two groups was evaluated using the identity test (Warren et al., 2008), whereas similarity of climatic niches along the (E)-space was analysed using the background similarity test, assessing whether the climatic niches among groups are less similar (divergent) or more similar (conserved) than expected by chance, accounting for the differences in the surrounding environmental conditions (Warren et al., 2008). For this test, we used 1000 repetitions and the null hypothesis was rejected if niche overlap of the observed value was lower or greater than the $95 \%$ of simulated values. All these analyses were conducted using the ecospat v.3.0 package (Di Cola et al., 2017; Broennimann, Di Cola \& Guisan, 2018).

For niche comparisons in the geographical (G) space, we applied species distribution modelling (SDM) to model distribution of $W$. spathulifolia groups using the maximum entropy algorithm implemented in Maxent v.3.4.1 (Phillips et al., 2017). Because inclusion of the 21 variables (19 biovar+IA+PET) in the SDM can be problematic due to high degrees of collinearity among predictors, we used principal components from the PCA-env rather than raw variables, retaining the first five PC (which accounted for $>95 \%$ of environmental variation). Maxent analyses were performed using ten cross validation runs with a maximum iterations of 1000 , logistic output and all other options were left as default (convergence threshold of $1 \times 10^{-5}, 1$ $\times 10^{4}$ background points, regularization multiplier of 1 , default prevalence of 0.5 and autofeatures). The area under the receiver operating characteristic curve (AUC) was used as a measure of model performance, and variable contribution to SDM was evaluated both through permutation importance and jackknife tests. Then, we conducted the identity and background similarity test in the phyloclim v.0.9.5 package (Heibl $\&$ Calenge, 2018) using the ecological niche models obtained for each group, the Schoener's $D$ index and 100 replicates.

Alternatively, we calculated the range overlap among NG and SCG using binary presence/absence maps derived from the SDM predictions. Since the choice of a threshold is a topic of ongoing debate, we used the threshold indicating maximum training sensitivity plus specificity, which is considered to be a more robust approach (Liu et al., 2005; Liu, White \& Newell, 2013). The degree of geographical-range overlap between the two groups was estimated following Barraclough \& Vogler (2000), as the ratio of the shared area to the area of the smaller ranged group. In this way, if one distribution range is contained within another, overlap is one (100\%). Finally, because we recognized here the NG and SCG lineages as two different species, we assessed their threat status according to IUCN categories and criteria (IUCN, 2017), calculating the extent of occurrence (EOO) for both groups with the Delaunay triangulation method proposed by Downs \& Horner (2009) and implemented in the adehabitatHR package, accounting for the area contained within $95 \%$ of the smallest triangles.

\section{RESULTS}

\section{PHYLOGENETIC ANALYSES}

Features of ITS, $t r n L-F$ and $t r n H-p s b A$ alignments are summarized in the Supporting Information (Table S2). Both ML and BI analyses with the ITS and plastid DNA (trnL-F+trn $H-p s b A)$ data recovered specimens of $W$. 
spathulifolia in two different clades, one including the specimens from the northern part of the geographical distribution range (the northern group, 'NG' clade) (ITS: $\mathrm{BS}=100 \%, \mathrm{PP}=100 \%$; plastid DNA: $\mathrm{BS}=99 \%$, $\mathrm{PP}=100 \%)$, and the other including the specimens from the southern-central geographical range (the southern-central group, 'SCG' clade) (ITS: BS $=94 \%$, $\mathrm{PP}=96 \%$; plastid DNA: $\mathrm{BS}=84 \%, \mathrm{PP}=96 \%)($ Figs 2 , S2). Additionally, analyses with plastid DNA data also retrieved a clade with the NG together with $W$. cymosa Al-Shehbaz and W. scabrifolia Al-Shehbaz (plastid DNA: $\mathrm{BS}=72 \%, \mathrm{PP}=98 \%)($ referred to as clade A, Figs 2, S2) and the SCG in a monophyletic group with $W$. arequipa Al-Shehbaz \& Montesinos, W. ayacuchoensis Al-Shehbaz, A.Cano \& Trinidad, W. densifolia Al-Shehbaz, W. herzogii
(O.E.Schulz) Al-Shehbaz, W. rosulans (O.E.Schulz) $\mathrm{Al}-$ Shehbaz and the genera Englerocharis Muschl. and Zuloagocardamum Salariato \& Al-Shehbaz (plastid DNA: BS $<50 \%, \mathrm{PP}=89 \%$ ) (referred as clade B, Figs 2 , S2). Trees from analyses of the individual plastid DNA regions are available from TreeBASE (http://purl. org/phylo/treebase/phylows/study/TB2:S24633), and Salariato (2019). ML and BI analyses of the concatenated ITS+plastid DNA dataset also recovered the NG and SCG clades of $W$. spathulifolia $(\mathrm{NG}$ : $\mathrm{BS}=99 \%, \mathrm{PP}=$ $100 \%$; SCG: $\mathrm{BS}=66 \%, \mathrm{PP}=100 \%$ ) and the clades $\mathrm{A}$ and $\mathrm{B}(\mathrm{A}: \mathrm{BS}<50 \%, \mathrm{PP}=97 \%$; $\mathrm{B}: \mathrm{BS}=60 \%, \mathrm{PP}=95 \%$ ), which included all Weberbauera spp. except $W$. peruviana and $W$. trichocarpha (Muschl.) J.F.Macbr. (Figs 3A, S3). Results from concordance analyses varying the discordance

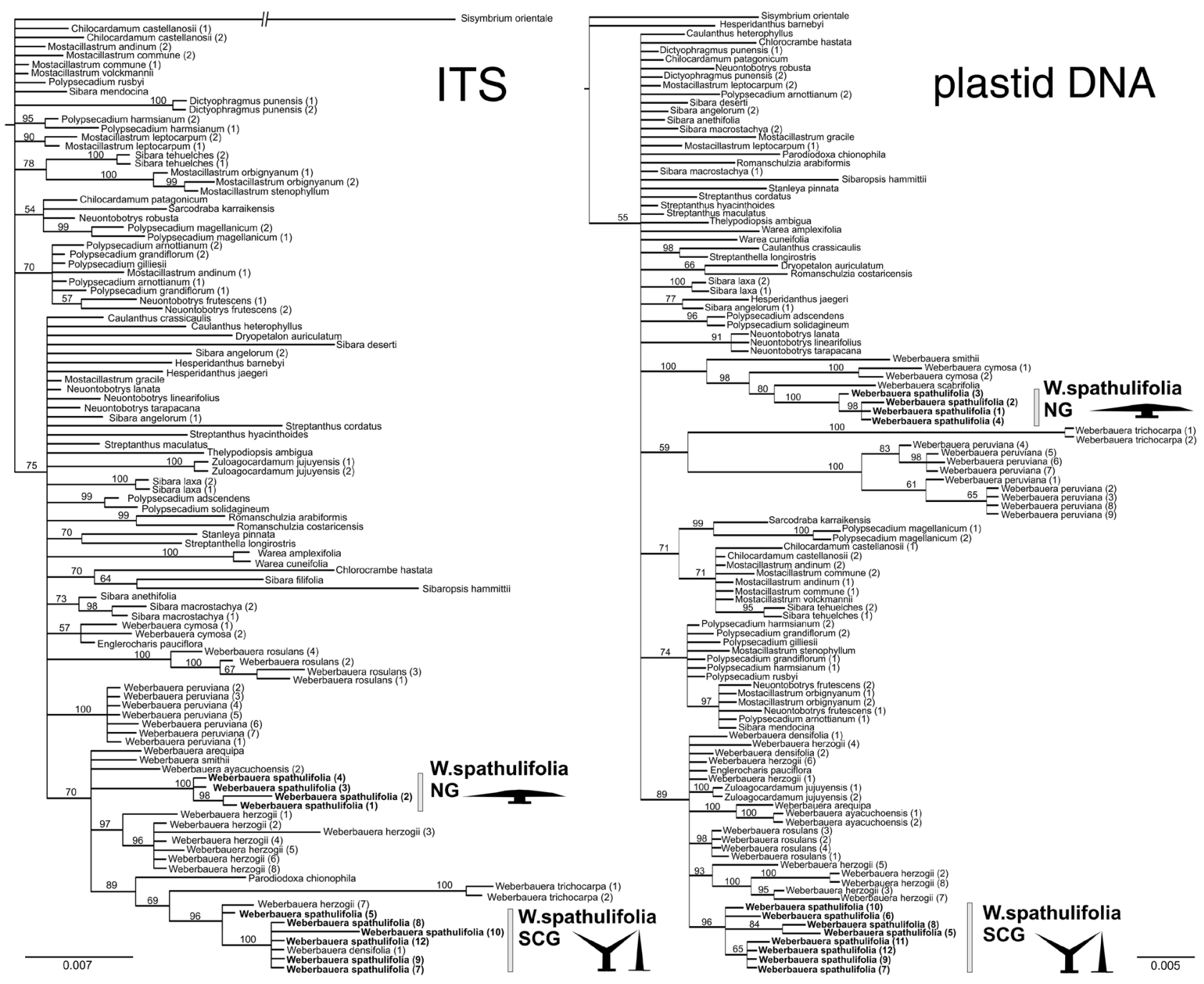

Figure 2. Bayesian 50\% majority-rule consensus trees from 6002 trees generated by Bayesian inference with MrBayes v.3.2.6 showing the phylogenetic placement of Weberbauera spathulifolia. Left, nrITS dataset. Right, plastid DNA dataset (trnL-F/trnH-psbA). Values on branches correspond to Bayesian posterior probability (\%). Units of branch length are proportional to nucleotide substitutions per site. NG: northern group of W. spathulifolia, SCG: southern-central group of W. spathulifolia. 
prior $(\alpha)$ had no effect on topology or concordance, and the primary concordance tree produced by BUCKy also recovered the NG and SCG clades (concordance factor 'CF' $=1$ and $<0.5$, respectively), as well as the clades $\mathrm{A}$ and $\mathrm{B}(\mathrm{CF}=0.5$ and $<0.5$, respectively) (Supporting Information, Fig. S4). Alternatively, when differences between the ITS and plastid DNA trees were represented graphically by a filtered supernetwork (in which cycles in the network represent conflicting phylogenetic signals) specimens of $W$. spathulifolia remained segregated in the NG and SCG lineages, despite the evidences of incongruence located within clades A and B, respectively (Fig. 3C). These results were confirmed by the $\mathrm{SH}$ and AU tests for the plastid DNA and the plastid DNA+ITS datasets, rejecting the hypothesis of monophyly of the $W$. spathulifolia $(P<0.01$, Table 1$)$, whereas with the ITS data it could not be rejected. BF analyses favoured the non-monophyly of the specimens with all datasets (Table 1). Finally, results from the species-tree analysis under the multispecies coalescent model were congruent with the concatenated analyses, recovering the NG and SCG clades, the first closely related to W. cymosa and W. scabrifolia and the second to W. densifolia, and $W$. herzogii (Figs 2B, S5). BFD favoured with positive support ( $2 \operatorname{lnBF}=4.4$ for PS and 6.1 for stepping-stone sampling) that specimens from NG and SCG represent two different species.

\section{MORPHOLOGICAL STUDIES}

Analyses of morphological characters in specimens of W. spathulifolia show that specimens from the NG and the SCG are distinguished by the trichome type (Fig. 4). Specimens from the NG exhibit exclusively malpighiaceous to submalpighiaceous trichomes mainly along the stems, but also in margins of leaves and pedicels (Fig. 4A-E). In contrast, specimens of the SCG vary from glabrous to pilose, but the trichomes are always simple or long stalked and forked (Fig. $4 \mathrm{~F}-\mathrm{I}$ ). Additionally, oblong or ovate to widely spatulate basal leaves seem to be more common in specimens of NG (Fig. 5A-C), whereas lanceolate to spatulate or linear basal leaves are more frequent in plants of the SCG (Fig. 5D-F). Likewise, petals in the NG appear to be longer than those of the SCG [3.0-5.0(-6.0) vs. 2.0-3.8(-4.0) $\mathrm{mm}$ long, respectively]. Nevertheless, these characters overlap between groups (Supporting Information, Table S3) and, therefore, are less reliable than the trichome type for their identification. Other qualitative and quantitative characters do not seem to be useful either. For the complete morphological descriptions see the Taxonomic Treatment section and the Supporting Information (Table S3).

\section{ECOLOGICAL NICHE COMPARISONS}

Eigenvalues and variable loadings for the PCA-env approach are shown in Table S4. The first three PCs accounted for $87.75 \%$ of the niche variation (48.03, 27.40 and $12.32 \%$, respectively). Variable loadings (Supporting Information, Table S4, Fig. S6) showed that the first component was primarily influenced by variables associated with precipitation: annual precipitation (BIO12), precipitation of the driest quarter/month (BIO17/BIO14) and the AI, whereas the second PC showed a higher correlation associated with temperature, mainly for the temperatures of the warmest month/quarter (BIO5/BIO10) and the annual mean temperature (BIO1). The third PC captures variation primarily related to describing the temperature oscillations, i.e. isothermality (day-to-night temperature variation relative to the annual variation, BIO3), temperature seasonality (temperature change over the course of the year, BIO4) and temperature annual range (BIO7). Thus, in the (E)-space load positive environments with higher precipitations for the first $\mathrm{PC}$, higher temperatures for the second PC and lower isothermality with wider temperature seasonality and annual range for the third PC (Supporting Information, Fig. S6). Occurrences from the NG and SCG were differentiated along the PC1 and PC3 (Figs 6A-C and S6) $(P>0.001)$, with members of the NG growing in habitats with higher precipitation and isothermality, but lower temperature seasonality. NG and SCG were not differentiated along the PC2 associated with temperatures $(P=0.139)$. Climatic niches occupied by NG and SCG in the (E)-space are shown in Fig. S7. The niche equivalency test recovered significant differences (non-equivalency) for NG and SCG $(P=0.001)$ (Table 2), whereas the similarity test did not recover significant similarity/difference between niches of these groups when the background space was considered.

Values of the AUC obtained in the SDM for NG and SCG resulted in $0.982(\mathrm{SD}= \pm 0.009)$ and $0.912( \pm 0.057)$ indicating good model performance (Fig. 6D, E, Table S5). The third component (temperature oscillation) was the variable that contributed most to the SDM of the NG, whereas for the SCG it was the second component (temperature) (Supporting Information, Table S5, Fig. S8). A niche equivalency test using the distribution models for NG and SCG rejected the equivalency of both niches in the $(\mathrm{G})$-space (Schoener's $D=0.093$, $P=0.01$ ), and a similarity test recovered significant differentiation for niches of NG and SCG $(P=0.02$ both when NG and SCG were randomized from the background area) (Table 2). Finally, the percentage of distribution area shared by both groups, and estimated using the binary presence/absence maps derived from the SDM predictions, was nearly zero (0.33\%) (Fig. $6 \mathrm{~F}$ ), 


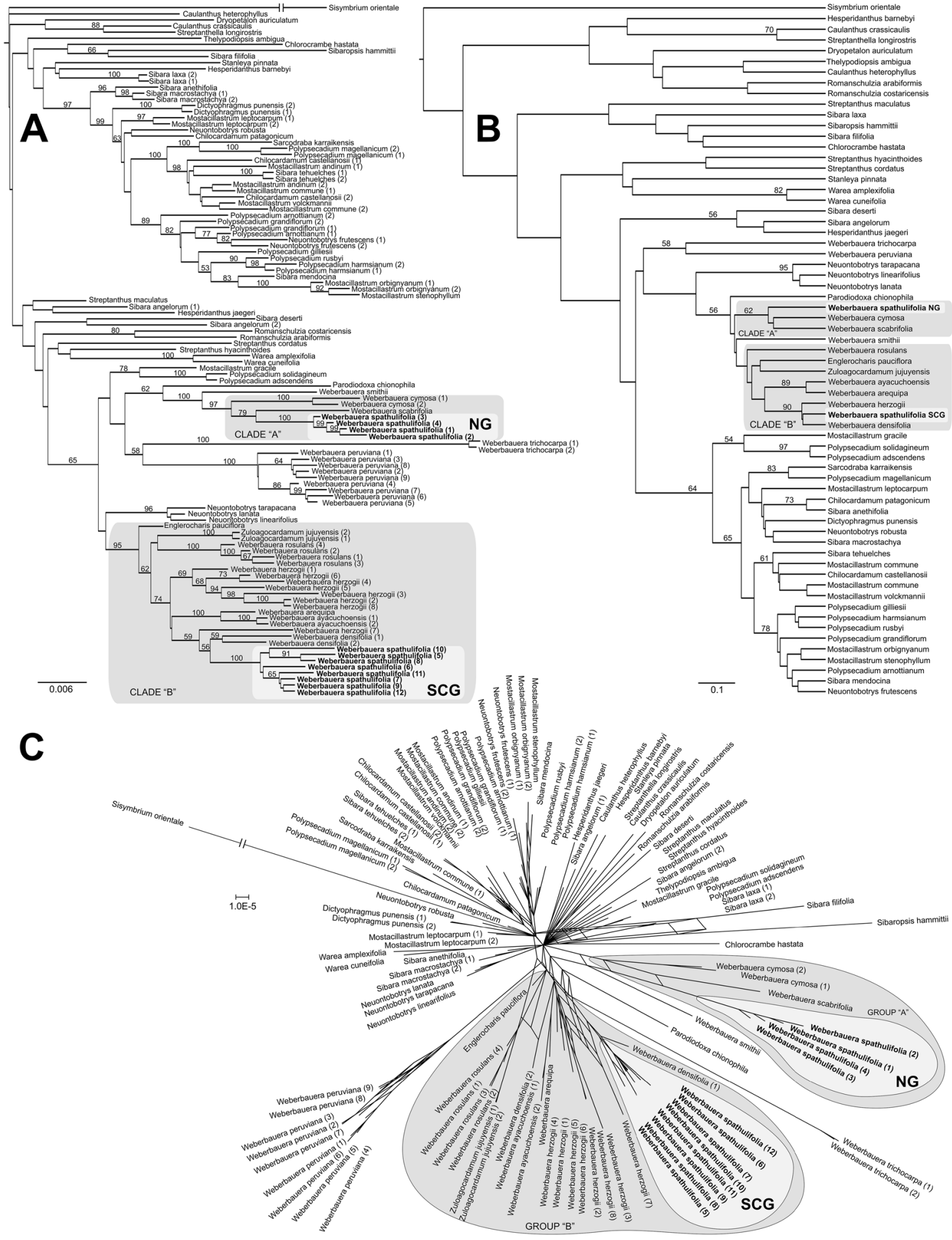

Figure 3. Phylogenetic placement of Weberbauera spathulifolia. A, Maximum clade credibility (MCC) tree generated by Bayesian inference with MrBayes v.3.2.6 and the concatenated ITS+plastid DNA (trnL-F/trnH-psbA) datasets. B, MCC species tree estimated from ITS and plastid DNA datasets using the multispecies coalescent method implemented in *BEAST v.1.8.4 and the hypothesis favoured by the Bayes-factor analysis (two species under W. spathulifolia). C, Filtered supernetwork generated in SplitsTree v.4.14.8 using 1000 Bayesian posterior trees per each nuclear ITS and plastid DNA dataset, and filtering the splits to show only those present in a minimum of $30 \%$ input trees). Values on branches in A and B correspond to Bayesian posterior probability (\%). Units of branch length are proportional to nucleotide substitutions per site. NG: northern group of W. spathulifolia, SCG: southern-central group of W. spathulifolia. 
Table 1. Comparisons of tree topology hypotheses for monophyly of Weberbauera spathulifolia by using SH test, AU test and Bayes-factor analyses. For SH and AU tests the monophyly was rejected when $P<0.05$; $2 \operatorname{lnBF}$ values were interpreted following criteria of Kass \& Raftery (1995): 0-2 'not worth more than a bare mention', 2-6 'positive' support, 6-10 'strong' support and > 10 'decisive' support for the non-monophyly of the species.

\begin{tabular}{lcrrr}
\hline Dataset & $\Delta \operatorname{lnL}$ (best tree vs. monophyly) & $P(\mathrm{SH})$ & $P(\mathrm{AU})$ & 2lnBF (non-monophyly/monophyly) \\
\hline ITS & 3.4 & 0.275 & 0.271 & 3.28 \\
plastid DNA & 61.8 & $<0.001$ & $<0.001$ & 68.19 \\
concatenated ITS+plastid DNA & 50.9 & $<0.001$ & $<0.001$ & 29.02 \\
\hline
\end{tabular}

supporting a strong allopatric distribution between NG and SCG.

\section{DISCUSSION}

Based on results from the molecular data, $W$. spathulifolia includes two not closely related lineages that can be differentiated by their morphology (trichome type), geographical range and climatic niche they occupy. Morphological and geographical variation in this species was previously noticed by Al-Shehbaz (1990), and although the author asserted that morphological variation within the species did not appear to be associated with geographical distribution, he also observed that the trichome type was the only character with apparent geographical structure (plants with malpighiaceus/submalpighiaceus trichomes are restricted to the northern portion of the species range). Among other Weberbauera spp., malpighiaceus trichomes are only found in $W$. trichocarpa, but this species is not closely related to the NG in our molecular analyses, and it is easily differentiated because trichomes densely cover stems, leaves, pedicels, sepals and fruits. Trichomes are highly diverse in Brassicaceae (Rollins \& Banerjee, 1976; Appel \& Al-Shehbaz, 2003) and, even though different types evolved multiple times in the family (Beilstein, Al-Shehbaz \& Kellogg, 2006; Beilstein et al., 2008), they are useful morphological characters for the delimitation of species and genera.

Distribution area and climatic niches in both lineages were also differentiated, with NG being restricted to the Andes of northern Peru (c. $8^{\circ} 7^{\prime} \mathrm{S}-12^{\circ} 49^{\prime} \mathrm{S}$ latitude) in the departments of Ancash, Huancavelica, Junín, Lima and Pasco, and SCG growing in the Andean highlands of southern Peru, Bolivia and northern Argentina and Chile (c. $14^{\circ} 3^{\prime} \mathrm{S}-29^{\circ} 08^{\prime}$ S latitude) (Fig. 1). Although the elevational range of both groups is similar ( $c$. $3800-4800 \mathrm{~m}$ ), the climatic niche of the SCG lineage was differentiated by lower precipitation and greater temperature variation over the year (measured as temperature seasonality and temperature annual range). Geographical range of the SCG lineage extends along the 'central Andean wet Puna', 'central Andean Puna' and 'central Andean dry Puna' ecoregions of Olson et al. (2001), whereas the NG lineage is fully included in the 'central Andean wet Puna'. Although the NG and SCG are allopatric, both lineages share sympatric ranges with their closely related species (W. scabrifolia and W. cymosa for the NG lineage and W. herzogii and W. densifolia for the SCG lineage). These results are in accordance with the evidence obtained for other South American Brassicaceae (Salariato et al., 2015, 2016, 2018; Salariato \& Zuloaga, 2017) in which sympatry or parapatry appear as a common geographical pattern between closely related species. However, patterns from geographical-range evolution are difficult to interpret due to the lability on the ancestral distributions (Losos \& Glor, 2003) and therefore, micro-allopatric diversification mediated by phylogenetic-niche conservatism (Wiens, 2004; Wiens \& Graham 2005; Pyron et al., 2015) should not be discarded as an important diversification process for Andean Brassicaceae.

Although this work was not intended to test monophyly of Weberbauera, the results obtained support the non-monophyly of the genus. Most of the species were included in clades A and B, but clade A also included Englerocharis and Zuloagocardamum. With Weberbauera, these genera share the distribution area along the central Andes and they are perennial herbs with rosulate basal leaves (Salariato, Zuloaga \& Al-Shehbaz, 2013; Salariato \& Al-Shehbaz 2014; Al-Shehbaz, 2017). In contrast, W. peruviana and W. trichocarpa were excluded from these clades, and further studies may support their transfer to independent genera. Our results suggest the potential paraphyly/polyphyly of this genus. However, low resolution of traditional molecular phylogenetic trees for South American Thelypodieae, added to the lack of robust morphological synapomorphies that support genera, complicates systematic delimitation in the tribe. Future analyses of genomic data generated using new sequencing technologies would be a promising solution for the resolution of the phylogenetic trees and systematics of these genera, as recently confirmed by Nikolov et al. (2019) for the family. Therefore, we prefer to avoid any taxonomic 

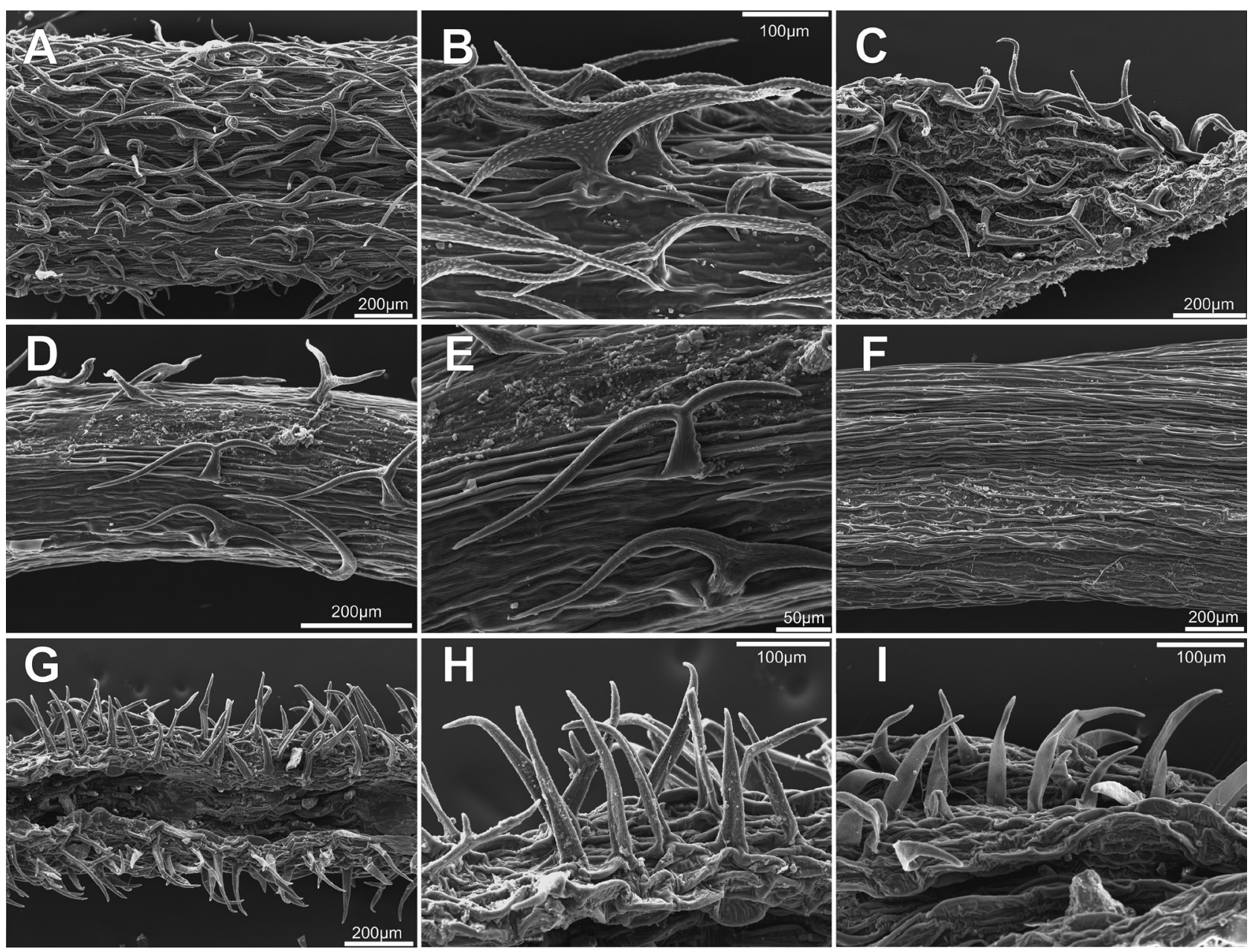

Figure 4. Trichomes in Weberbauera spathulifolia. A-E, malpighiaceous to submalpighiaceous trichomes in specimens of the northern group (NG). A, trichomes on the stem; B, detail; C, trichomes on basal leaves; D, trichomes on the pedicel and E, detail. F-I, simple and stalked forked trichomes in specimens of the southern-central group (SCG). F, stem glabrous; G, trichomes on basal leaves; H, detail and I, trichomes on caulinar leaves. A-E from Salariato \& Trinidad 56 (SI), F-I from Donadio et al. 122 (SI).

changes to the circumscription of Weberbauera until we have more robust data.

Because the evidence obtained in this work leads us to recognize two different lineages within $W$. spathulifolia s.l., we propose to retain the species name to the NG lineage and recognize the SCG lineage as W. orophila (三Sisymbrium orophilum Wedd.), the earliest name in the W. spathulifolia s.l. for the SCG group (see below).

\section{TAXONOMIC TREATMENT}

\section{KEY DISTINGUISHING WEBERBAUERA SPATHULIFOLIA FROM W. OROPHILA}

1. Plants with malpighiaceous to submalpighiaceous trichomes mainly along stems, less frequently along leaf margins and on pedicels W. spathulifolia
1'. Plants glabrous or with simple and/or stalked forked trichomes mainly on leaves, less frequently along stems W. orophila

1. Weberbauera spathulifolia (A.Gray) O.E.Schulz in Engler, Pflanzenreich IV. 105(Heft 86): 193. 1924. Sisymbrium spathulifolium A.Gray, U.S. Expl. Exped. Phan. 15(1): 60. 1854. Hesperis spathulifolia (A.Gray) Kuntze, Revis. Gen. Pl. 2: 935. 1891. Type: Peru, [Junín], Obrajillo, Wilkes Expedition, anonymous [holotype US-US00036551! (https:// collections.nmnh.si.edu/search/botany/?ark=ark:/6 5665/3a4ce80c7f44040109fb52aa7ffe3a4ee); isotype P- P02141450! (https://science.mnhn.fr/institution/ $\mathrm{mnhn} /$ collection/p/item/p02141450?listIndex=5\&list Count=5)].

Braya densiflora Muschl., Bot. Jahrb. Syst. 40: 275. 1908. Weberbauera densiflora (Muschl.) Gilg \& Muschl., 

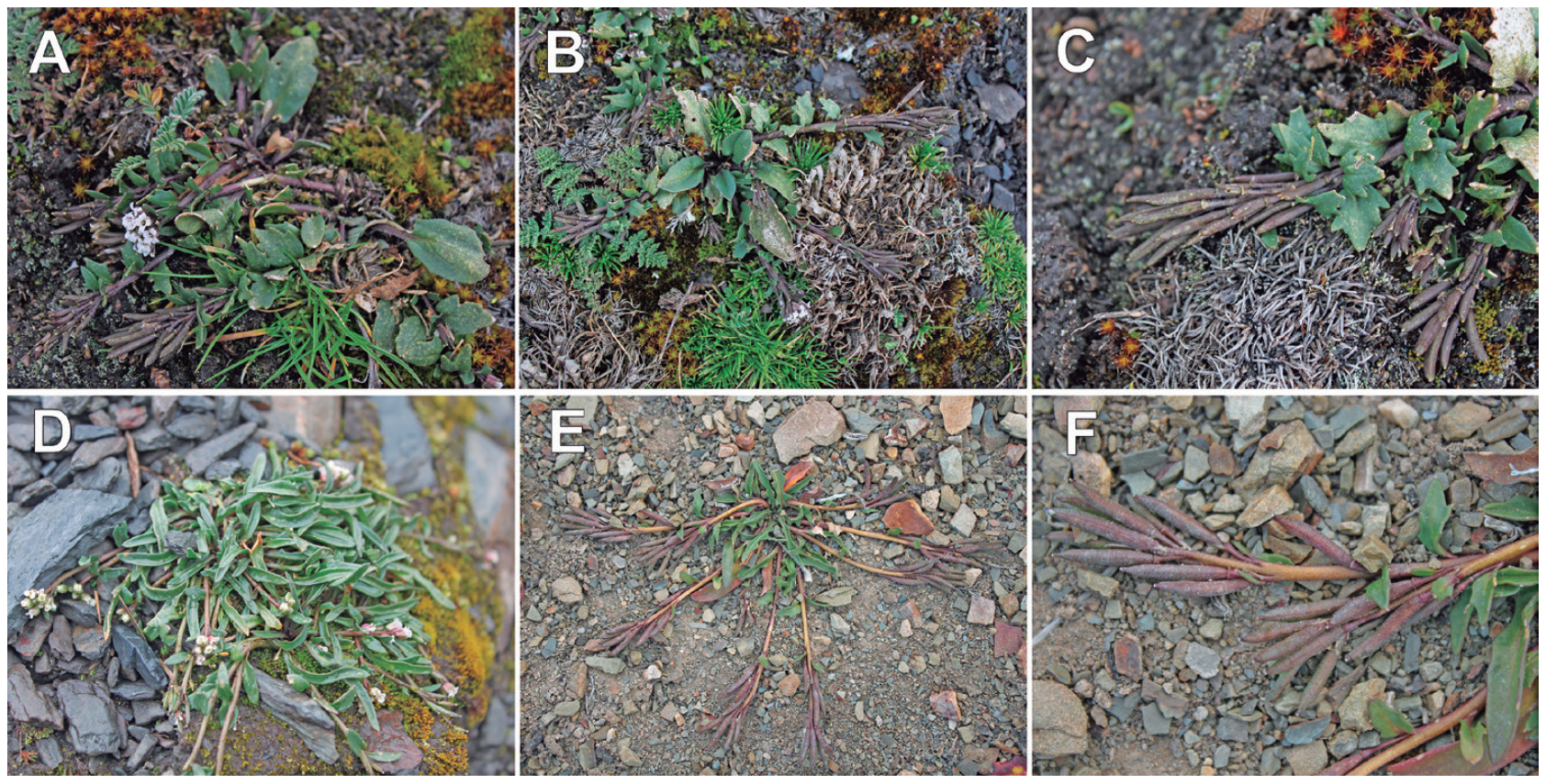

Figure 5. Weberbauera sphathulifolia specimens from the northern (NG) and southern-central (SCG) group, and their habitat. A-C, northern group. A, plant with flowers; B, plant with fruits and C, detail of fruits. D-F, southern-central group. D, plant with flowers; E, plant with fruits and F, detail of fruits. A-C from Salariato \& Lliully Aguilar 21 (SI), D-F from Zuloaga et al. 16299 (SI). Photographs by Diego L. Salariato.

Bot. Jahrb. Syst. 42: 481. 1909. Type: Peru, Hacienda Arapa, Yauli, Lima-Oroya rd., 4400 m, A. Weberbauer 304 [lectotype (designated by Macbride 1938) B!; isolectotype G-G00383991! (https://plants.jstor.org/ stable/viewer/10.5555/al.ap.specimen.g00383991)].

Weberbauera spathulifolia var. integrifolia O.E.Schulz, Publ. Field Mus. Nat. Hist. Bot. Ser. 8: 80. 1930. Type: Peru, [Dep. Lima], Río Blanco, 8-19 May 1922, $1500 \mathrm{ft}$ [4572 m], J. F. Macbride \& Featherstone 811 [holotype F-F0042184! (https://plants.jstor.org/stable/ viewer/10.5555/al.ap.specimen.f0042184f); isotype GH!].

Caudex simple or sometimes branched, slender, usually covered with petiolar remains of previous years. Trichomes mainly along stems and less frequently along leaf margins and on pedicels, malpighiaceous to submalpighiaceous on stalk $<0.1 \mathrm{~mm}$. Stems decumbent, simple, (2-)3-17(-26) cm tall, pubescent. Basal leaves with petiole (0.5-)1.0-4.0 cm long, blade oblong or ovate to spatulate, rarely lanceolate, $(1.0-) 2.0-3.5(-5.0) \times$ $0.3-1.0(-1.6) \mathrm{cm}$, glabrous or pubescent principally at margins, margin entire or repand to dentate, apex obtuse; cauline leaves subsessile, blade oblong to obovate, entire to repand or dentate. Racemes bracteate or ebracteate, lax to compact in fruit, $(0.8-) 1 .-7.0(-11.0) \mathrm{cm}$ long; fruiting pedicels $3-6(-8) \mathrm{mm}$ long, pubescent or glabrous, straight or curved, ascending, base subappressed. Sepals oblong to ovate, $2.0-3.0(-4.0) \times 1.0-1.5 \mathrm{~mm}$, caducous, sparsely pubescent to glabrous, margin scarious, apex obtuse; petals white, spatulate, $3.0-5.0(-6.0) \times$
1.5-2.0(-2.5) $\mathrm{mm}$, attenuate to clawlike base; filaments white, 2.0-3.0(-3.5) $\mathrm{mm}$ long; anthers oblong to ovate, $0.8-1.1 \mathrm{~mm}$ long. Fruit linear to oblong, 8.0-18.0(-20) $\times$ (1.2-)1.5-1.8 mm, divaricate to erect and subappressed to rachis, straight or frequently curved, terete; valves smooth, glabrous, obscurely to conspicuously veined; style 0.4-0.8(-1.5) mm long. Seeds light to dark brown, oblong to ovate, $1.0-1.4 \times 0.6-0.8 \mathrm{~mm}$, subbiseriate; cotyledons incumbent. Figs $5 \mathrm{~A}-\mathrm{C}, 7$.

Distribution and habitat: northern Peru (Ancash, Huancavelica, Junín, Lima and Pasco) (Fig. 1). This species grows on rocky, sandy, or clayey areas along slopes of the central Andean wet Puna (ecoregion sensu Olson et al., 2001), between 3900-4800 m.

Phenology: Flowers mainly from February to April and fruits until May.

Conservation status: Following the IUCN red list categories and criteria (IUCN, 2017), and based in the $\operatorname{EOO~(c.~} 33857 \mathrm{~km}^{2}$ ) and the number of localities where it has been collected, W. spathulifolia can be categorized as least concern (LC).

Additional specimens examined: (numbers in boldface indicate specimens used in phylogenetic analyses): PERU. Ancash: BolognesI, Aquia, A. Cano 12366 (USM); between Tallenga and Pachapaqui, $E$. 

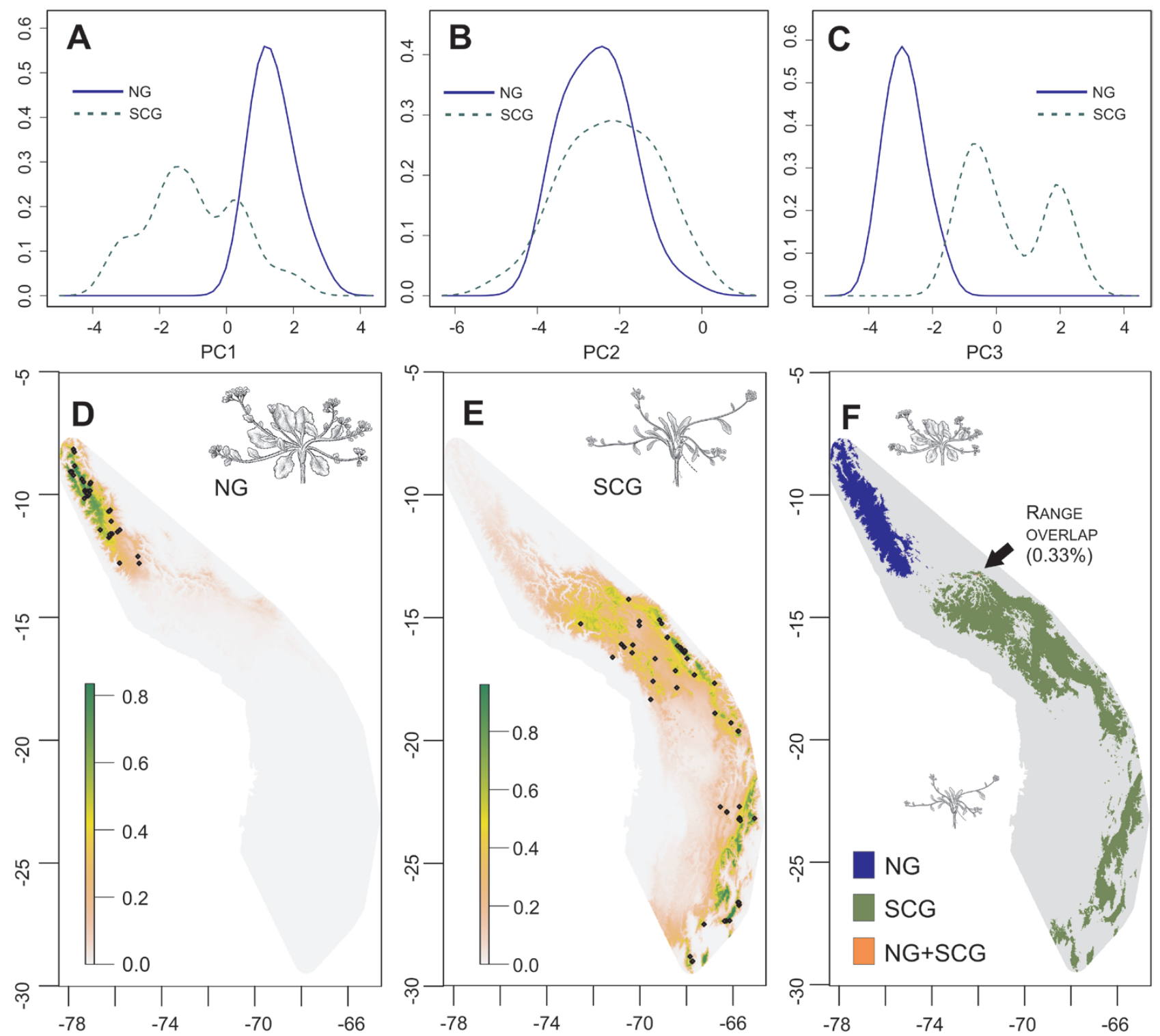

Figure 6. Results from the niche comparisons in the environmental (E) and geographical (G) spaces. A-C, density plots computed for northern (NG) and southern-central (SCG) groups of Weberbauera spathulifolia using the PC1 (A), PC2 (B) and PC3 (C); solid blue line corresponds to NG, green dashed line to SCG. D-F, results from the species distribution modelling (SDM). D, E, predicted suitable climatic conditions (logistic output) from the MaxEnt model for NG (D) and SCG (E) groups of W. spathulifolia using the first five principal components of the PCA-env as climatic variables. Dots represent specimen occurrences used for the SDM analyses. F, binary (presence/absence) distributions maps for NG and SCG derived from the SDM outputs using the maximum training sensitivity plus specificity as threshold. Blue cells indicate presence of NG, green cells presence of SCG, and red cells indicate presence of both NG and SCG. The arrow indicates the estimated area of sympatry $(0.33 \%)$.

Cerrate 749 (GH); road from Chiquían to Huallanca, $M$. Weigend 5201 (NY); road from Huallanca to San Marcos via Lago Canrash, north of Lago Canrash, $M$. Weigend et al. 8853 (USM); Tinya, Valle del Fortaleza, E. Cerrate 2671 (USM); Yanashalla, cerros cercanos al abra, pasando minera Pachapaqui, D. Salariato \& H. Trinidad 86 (SI, USM) (4); CARHUAZ, Huascarán
National Park, Quebrada Ishinca, D. Smith et al. 9440 (MO, USM); HuARAZ, Huascarán National Park, Shallap, terminal moraine below lake, D. Smith et al. 9670 (USM, F, MO); HUARI, JUPROG, Antamina, $A$. Cano 12807 (USM); Antamina, A. Cano 12808 (USM); Huaylas, C. Rico, Pamparomás, C. Monsalve \& A. Cano 15 (USM), C. Monsalve \& A. Cano 22 (USM), C. 
Table 2. Pairwise niche overlap values using the Schoener's $D$ metric and $P$-values of niche identity and similarity tests for groups (NG and SCG) of Weberbauera spathulifolia in the environmental (E) space (PCenv1-2, PCenv1-3, PCenv2-3) and the geographical (G) space (SDM). Comparisons under identity test with $P<0.05$ (in bold) indicate that niches of NG and SCG are not equivalent, whereas comparisons under similarity test with $P<0.05$ indicate that niches of NG and SCG are more dissimilar or similar than expected by chance. Superscripts: $\left({ }^{a}\right)=$ more dissimilar than expected by chance.

\begin{tabular}{lllll}
\hline & Overlap (D) & Niche identity & \multicolumn{2}{l}{ Niche similarity } \\
\cline { 3 - 4 } & & & NG $\rightarrow$ SCG & \\
\hline (E)-space & & & 0.543 & 0.507 \\
PCenv1-2 & 0.062 & $\mathbf{0 . 0 0 1}$ & 0.789 & 0.334 \\
PCenv1-3 & 0.000 & $\mathbf{0 . 0 0 1}$ & 0.324 & 0.799 \\
PCenv2-3 & 0.016 & $\mathbf{0 . 0 0 1}$ & & $\mathbf{0 . 0 2 0}^{\mathbf{a}}$ \\
(G)-space & 0.093 & $\mathbf{0 . 0 1 0}$ & $\mathbf{0 . 0 2 0}^{\mathbf{a}}$ \\
SDM & &
\end{tabular}

Monsalve \& A. Cano 24 (USM); Huascarán National Park, Quebrada Los Cedros, cerro Alpamayo, $D$. Smith et al. 9924 (USM, F, GH, MO); Huashta Cruz, Pueblo Libre, J. Roque et al. 2611 (USM); Matacoto, J. Roque et al. 1485 (USM); Pueblo Libre, cumbre del Huastha Cruz, M. I. La Torre et al. 2721 (USM), 2724 (USM), 2725 (USM) (3); Riurín, A. Cano 9238 (USM); PAllasCA, Cerros cercanos a la laguna Pelagatos, $D$. Salariato \& H. Trinidad 56 (SI, USM) (1); Conchucos, cerros de Altos de Patría, D. Salariato \& H. Trinidad 53 (SI, USM) (2); RECUAY, collado arriba río Pumapampa, O. Tovar et al. 9716 (USM); Huascarán National Park, pass between Nevado Pasto Ruri and Nevado Raria, Río Pachacoto, D. Smith \& F. Escalona 10182 (MO, USM); Quebrada Quenua Ragra, D. Smith et al. 11730 (USM); Quebrada Queshque, lateral valley near Río Pachacoto, D. Smith et al. 11845 (MO, USM); Huascarán National Park, Río Pachacoto, C. Todzia et al. 2593 (MO); Río Pachacoto drainage, $15 \mathrm{~km}$ from paved highway, D. Smith et al. 9373 (MO, USM); Río Pachacoto drainage, between mineral springs and Pumashimi, D. Smith \& M. Torres $11782 A$ (USM); Pachacoto, A. Cano et al. 11443 (USM). Huancavelica: HuANCAVEliCA, Bunbunya, al O de Conaica, O. Tovar 219 (USM, GH); Vichi, E. Proaño 26 (USM); Visco, J. F. Macbride \& W. Featherstone 590 (F, G, NY). Junín: Junín, Ondores, Pattersson 293 (S); TARMA, between Tarma y La Oroya, A. Weberbauer 2550 (B); YAULI, Morococha, Huapaya s.n. (S); Vicinity of Oroya, $M$. Kalenborn 132 (GH, KY). Lima: CANTA, Obrajillo, Wilkes Expedition, anonymous s.n (US, NY, P); HuARochIRI, Saltacuna, J. Soukup 1940 (US); Ticlio Bajo, L. Diers 979 (GH); Casapalca, E. Asplund 11425 (S); Río Blanco, J. F. Macbride \& W. Featherstone 811 (F), J. F. Macbride 2991 (CONC, F, NY); YAUYOS 17 km to Tupe, E. Cerrate 1226 (GH). Pasco: PASCO, between Cerro de Pasco and La Quinua, E. Asplund 11871 (S); cerca de Pasco, J. F. Macbride 3065 (CONC), J. F.
Macbride $3065 b$ (CONC); Cerro de Pasco, E. Asplund 11779 (S).

Weberbauera orophila (Wedd.) Salariato \& Al-Shehbaz comb. nov. Sisymbrium orophilum Wedd., Ann. Sci. Nat. Bot. 5(1): 288. 1864. Hesperis orophila (Wedd.) Kuntze, Revis. Gen. Pl. 2: 935.1891. Type: Bolivia, Prov. Larecaja, vicinity of Sorata, near Anilaya, Juriguana, 4500 m, G. Mandon 914 bis [holotype P-P02141448! (https://plants.jstor.org/ stable/viewer/10.5555/al.ap.specimen.p02141448); isotypes BM- BM000522278! (https://plants.jstor.org/ stable/viewer/10.5555/al.ap.specimen.bm000522278), G-G00383976! (https://plants.jstor.org/stable/ viewer/10.5555/al.ap.specimen.g00383976), K!K000485087 (https://apps.kew.org/herbcat/getImage. do?imageBarcode $=\mathrm{K} 000485087), \mathrm{P}-\mathrm{P} 02141447$ ! (https://plants.jstor.org/stable/viewer/10.5555/al.ap. specimen.p02141447)].

Sisymbrium oliganthum Wedd., Ann. Sci. Nat. Bot. 5(1): 289. 1864. Type: Bolivia, rochers de La Laucha, Corillera de La Paz, 1851, H. A. Weddell s.n. [holotype P-P02141446! (https://plants.jstor.org/stable/ viewer/10.5555/al.ap.specimen.p02141446? page=2)].

Sisymbrium septaceum Wedd., Ann. Sci. Nat. Bot. 5(1): 289. 1864. Type: Bolivia, Potosí, D’Orbigny 1447 [holotype P-P02141449! (https://plants.jstor.org/stable/ viewer/10.5555/al.ap.specimen.p02141449), isotype BAA!].

Caudex simple or branched, slender, usually covered with petiolar remains of previous years. Trichomes long stalked and forked, or simple, rarely absent. Stems decumbent, simple, (2.5-)4.0-12.0(-22.0) cm tall, usually glabrous, less frequently pubescent. Basal leaves with petiole(0.5-)1.0-3.5 cm long, blade lanceolate to spatulate or linear, rarely ovate, (1.0-)1.5-4.0 (-6.0) $\mathrm{cm} \times 1.0-$ $5.0(-10.0) \mathrm{mm}$, glabrous or pubescent, margin repand to dentate or lyrate-pinnatifid, apex obtuse or rarely acute; cauline leaves subsessile to short petiolate, blade oblong 

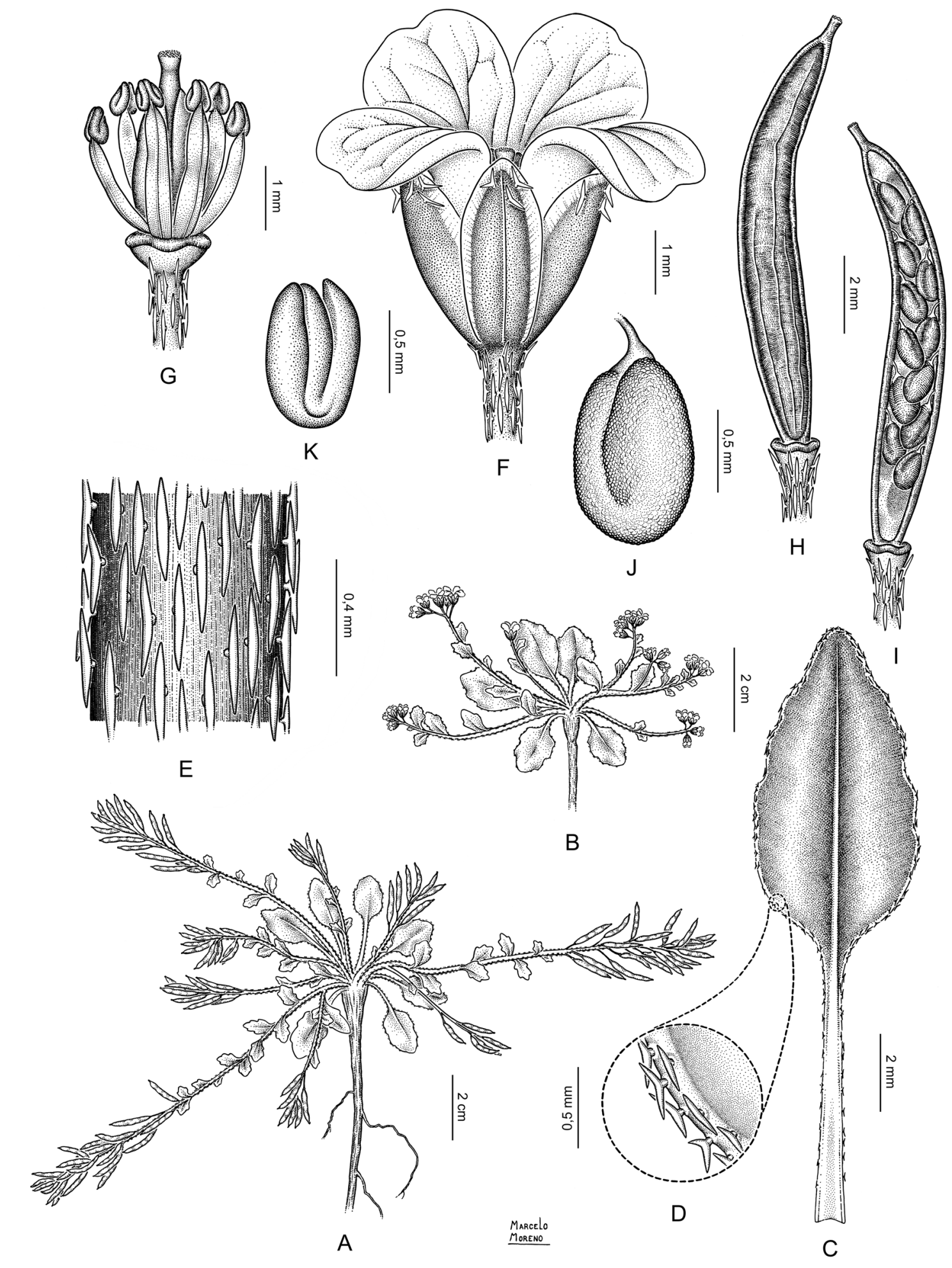

Figure 7. Weberbauera spathulifolia. A, plant with fruits; B, plant with flowers; C, basal leaf; D, detail of margin of the basal leaf showing malpighiaceous trichomes; E, detail of stem showing malpighiaceous trichomes; F, flower; G, stamens and ovary; H, fruit (silique); I, ovules/seeds of one of the locules; J, seed and K, embryo. From Salariato \& Trinidad 86 (see Supporting Information). 


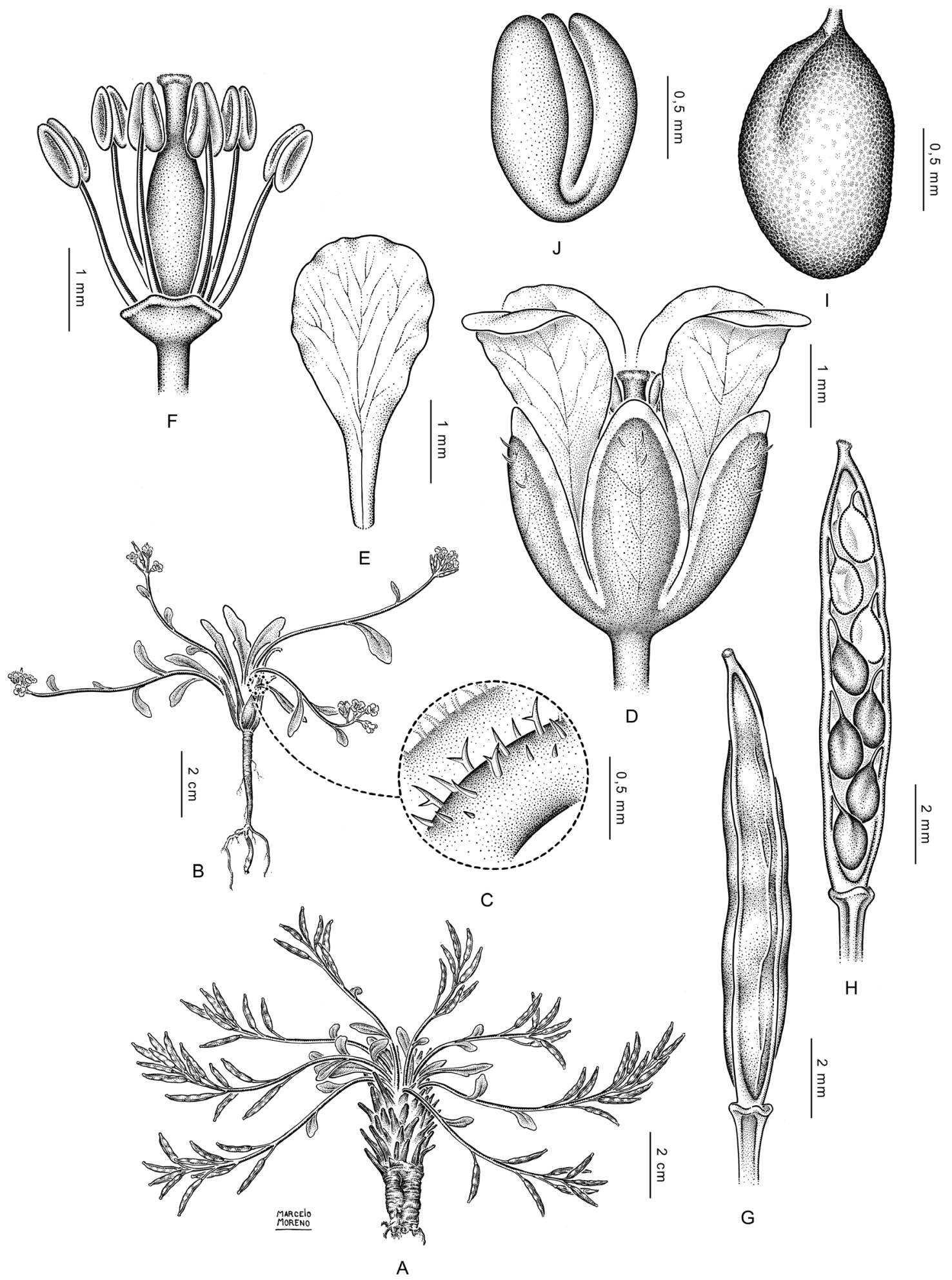

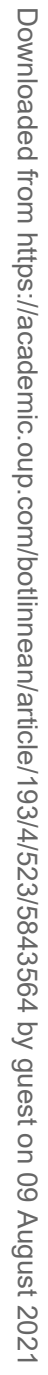

Figure 8. Weberbauera orophila. A, plant with fruits; B, plant with flowers; C, detail of margin of the basal leaf showing simple and stalked forked trichomes; D, flower; E, petal; F, stamens and ovary; G, fruit (silique); H, ovules/seeds of one of the locules; I, seed and J, embryo. From Donadio et al. 122 (SI). 
to obovate or lanceolate, entire to repand or dentate. Racemes bracteate or ebracteate, lax to compact in fruit, (1.0-)1.5-5.0(-8.0) cm long; fruiting pedicels (2-)3-8 $\mathrm{mm}$ long, straight or curved, ascending, subappressed at base. Sepals oblong to ovate, (1.5-)2.0-2.8(-3.0) × (0.8)1.0-1.5 mm, caducous, sparsely pubescent to glabrous, margin scarious, apex obtuse; petals white, spatulate, $2.0-3.8(-4.0) \times 1.5-1.8(-2.0) \mathrm{mm}$, attenuate to clawlike base; filaments white, $1.2-2.5 \mathrm{~mm}$ long; anthers oblong to ovate, $0.5-0.8 \mathrm{~mm}$ long. Fruit linear to oblong, (6.0) $8.0-15.0(-18.0) \times(1.0-) 1.2-1.8(-2.0) \mathrm{mm}$, divaricate to erect and subappressed to rachis, straight or curved, terete, usually abruptly ending in style; valves smooth, glabrous, obscurely to conspicuously veined; style $0.2-$ 0.8(-1.2) mm long. Seeds light to dark brown, oblong to ovate, $(0.8-) 1.0-1.5 \times 0.6-1.0 \mathrm{~mm}$, subbiseriate; cotyledons incumbent. Figs 5D-F, 8.

Distribution and habitat: southern Peru (Arequipa, Puno, Moquegua), Bolivia (La Paz, Oruro, Cochabamba, Potosí) and northern Argentina (Jujuy, Tucumán, Catamarca, La Rioja) and Chile (Arica y Parinacota) (Fig. 1). This species inhabits rocky and sandy areas along the highlands of the central Andean wet Puna, central Andean Puna, and central Andean dry Puna (ecoregions sensu Olson et al., 2001), mainly between 3800-4800 m.

Phenology: Flowers mostly from January to March and fruits until April.

Conservation status: Based in its EOO (c. 211637 $\mathrm{km}^{2}$ ) and the number of localities where it has been collected, Weberbauera orophila can be categorized as LC (IUCN, 2017).

Nomenclatural notes: Sisymbrium orophilum, S. oliganthum and $S$. septaceum were simultaneously published by Weddell (1864). The latter two are synonymized here under the first, of which the type is more complete. Therefore, $S$. orophilum will have priority over the other two (see Article 11.5 in Turland et al., 2018).

Additional specimens examined (numbers in bold indicate specimens used in phylogenetic analyses): ARGENTINA. Catamarca: ANDALGALÁ, Cerca de Mina Capillitas, alrededores del Globo Meteorológico, L. Salomón et al. 241 (SI) (9); Cerro de la Tambilla, P. Jörgensen 1837 (SI); Río Potrero Sup., H. Sleumer 1905 (LIL); subida al cerro Yutuyaco desde capillitas, H. Sleumer 2721 (BAA, LIL); BELÉN, Faldeo Sur de las cumbres de las Bayas, Potrerillos cerca de Granadillas, H. Sleumer \& F. Vervoorst 2635 (LIL). Jujuy: CochinocA, RP 74, $47 \mathrm{~km}$ de Mina Pirquitas, camino a Abra Pampa, Sierras de Quichagua, $O$.
Morrone et al. 2632 (SI), O. Morrone et al. 2644 (SI); HumahuaCA, $10 \mathrm{~km}$ de Cianzo camino a Santa Ana, Abra de Zenta, RP 73, O. Morrone et al. 2507 (SI), Mina Aguilar, A. Cabrera 19015 (LPB), Mina Aguilar, A. Cabrera \& J. Frangi 20700 (BAA); Mina Aguilar, B. Ruthsatz 1521 (BAA); Mina Aguilar, arriba del Molino, H. Sleumer $3402 b$ (LIL); Mina Aguilar, camino a La Poma, F. O. Zuloaga et al. 13561 (SI) (8); Mina Aguilar, toma de agua de la vega, B. Ruthsatz s.n. (BAA); Mina Aguilar, toma de agua del Molino, B. Ruthsatz 1537 (BAA), B. Ruthsatz 9760 (BAA); Mina Aguilar, veta, B. Ruthsatz 2239 (BAA); Ruta Provincial 73, Abra de Zenta, F. O. Zuloaga et al. 16299 (SI) (7); RINCONADA, Mina Pirquitas, H. Schwabe et al. $721 b$ (BAA); Pirquitas, cerros al W, A. Cabrera 9377 (BAA). La Rioja: FamatinA, Bajando desde Cueva de Pérez antes de llegar a las Cuevas de Noroña, G. Barboza et al. 2619 (CORD) (10); Cueva de Pérez, G. Barboza et al. 2583 (CORD) (11); G. Cueva de Pérez, G. Hieronymus \& G. Niederlein 376 (CORD); Cueva de Pérez, camino a la mina la Mejicana, S. Donadío et al. 122 (SI) (12); ladera este de Paso del Tocino, A. Krapovickas \& A. Hunziker 5345 (BAA). Tucumán: TAFí, Cumbres Calchaquíes, L. Castillón 284 (LIL), L. Castillón s.n. (LIL 53240) (BAA); Cumbres Calchaquíes, S. Haloy 734 (BAA); Filo Norte del Cerro Bayo (Alto de la Nieve); Cumbres Calchaquíes, S. Haloy 752 (BAA). BOLIVIA. Without locality, T. C. Bridges s.n. (K). Cochabamba: TAPACARÍ, Ajnuni, Aynoka Castilluma, comunidad de Japo ( $\mathrm{km}$ 125 Cochabamba-Oruro), H. Pestalozzi 797 (LPB), $H$. Pestalozzi 1055 (LPB). La Paz: Aroma, Huaraco, Fisel U. 472 (LPB); Huaraco, barbecho viejo, U. Fisel 188 (LPB) (6); BAUTISTA SAAVEDRA, $1 \mathrm{~km}$ Pumazi hacia Escoma, T. Feuerer 7285 (LPB), T. Feuerer 7641 (LPB); rocas en el paso a Curva, X. Menhofer 1797 (LPB); LARECAJA, vicinity of Combaya, G. Mandon 914 (BM, G, P, K); Los ANDES, al Este de Tuni, cerca restos de casas abandonadas arriba de la represa Racacha, $S$. G. Beck 33484 (LPB); Bajando del Cerro Paco Thojo, $S$. G. Beck 33488 (LPB); localidad Tuni, $65 \mathrm{~km}$ al N de La Paz, en ladera al E del cerro Mulamaniya y quebrada, afluentes al río Paya Huichinta, al NNE Lago Tuni, $\mathrm{N}$ de la Estancia Tuni, A. Garitano Zavala 1 (LPB); Murillo, c. $15 \mathrm{~km}$ NNE de La Paz. Pie del Nevado Chacaltaya, S. G. Beck 9130 (LPB); Chuquiaguillo, $15 \mathrm{~km}$ de La Paz, camino a Yungas, A. Krapovickas \& A. Fuchs 6755 (LIL); Cordillera Real, de la Laguna Larankhota hacia el Cerro Wila Manquilizani, S. G. Beck 14882 (LPB, MO); La cumbre, road to Undavi, J. Solomon 5029 (MO); c. $10 \mathrm{~km}$ hacia Los Yungas, turbera al Norte de la represa Incachaca, S. G. Beck 11139 (LPB); Calacoto $22 \mathrm{~km}$ hacia el SE por Collana, S. G. Beck 4290 (LPB, GH); Laguna pasando estancia Koluyo, M. Montes 746 (LPB); NNE de La Paz, Valle Achachicala, $5 \mathrm{~km}$ arriba de Kaluyo, S. G. Beck 27997 (LPB); OMASUYOS, Hichucota, primera laguna desde 
La Paz, ladera de los cerros, D. Salariato \& A. Lliully Aguilar 21 (SI, LPB) (5); PACAJES, Chañara, E. Asplund 2664 (S, UPS), E. Asplund 6201 (UPS); Corocoro, $E$. Asplund 2418 (S, UPS); Panacachi, E. Asplund 2582 (S). Oruro: EdUARDo Avaroa, Challepata, E. Asplund 3293 (UPS); SAJAMA, Curahuara de Carangas, $2 \mathrm{~km}$ hacia Turco, Puna Semi-arida, S. G. Beck 21018 (LPB). Potosí: FríAS, c. $25 \mathrm{~km} \mathrm{~N}$ of Yocalla towards Ventanilla, J. R. I. Wood 11743 (LPB); Cerro Potosí, E. Petersen \& J. Hjierting 1030 (BAA, LIL); Potosí, M. Cárdenas 398 (CONC). CHILE. XV Arica y Parinacota: PUTRE, Portezuelo de Chapiquiña, Faldeos al lado Norte del Campamento, C. Marticorena et al. 109 (CONC). PERU. Arequipa: CASTILla, Minas de Poracota. Providencia, H. Beltran 7066 (USM). Moquegua: GENERAL SANCHÉZ CERro, Cordillera above Torata, A. Weberbauer 7471 (CONC, F, G, S); Sura-Ccasuyama, cueva muy húmeda, D. Montesinos 3712 (USM); $4 \mathrm{~km} \mathrm{~W}$ of Coalaque locality near to Pacosani Lake, Yaretal, D. Montesinos 2414 (USM). Puno: AZÁngaro, Cerros alrededor de Tequena, P. Aguilar 220 (USM); CHUCUÍTo, Limite entre las comunidades Condor Ancocahua, Ingenio y Ancomarcas, A. Rámirez 2000-16 (USM); HUANCANE, Antapampa, Vargas 6837 (F); MELGAR, road from Rosario to Macusani, M. Weigend 2000 / 69 (NY); PUNO, San Antonio de Esquilache, Saundeman 3954 (K); Huaychuni, C. Aedo \& A. Galán de Mera 11268 (USM).

\section{ACKNOWLEDGEMENTS}

This work was funded by ANPCyT (Agencia Nacional de Promoción Científica y Tecnológica) grant PICT-2016-0096, CONICET (Consejo Nacional de Investigaciones Científicas y Técnicas) grant PIP112-201301-00124CO, and the National Geographic Society grant number 9841-16, for which we are profoundly grateful. Botanical collections we conducted under the permits: APN number 1103 (Argentina), VMABCC number 026/09 (Bolivia), SERNANP-PNH CUT number 001297-2017 and SERFOR/DGGSPFFS AUT-IFL number 2016-036 (Peru). We thank the directors, curators and collection managers of the herbaria listed. Special thanks to Lone Aagesen, Juan M. Acosta and Ariel Lliully Aguilar for their help in the fieldtrips, Marcelo Moreno for preparing the line drawings and Fabián Tricarico (Museum of Natural Sciences 'Bernardino Rivadavia') for his help with the scanning electron microscopy.

\section{REFERENCES}

Al-Shehbaz IA. 1990. A revision of Weberbauera (Brassicaceae). Journal of the Arnold Arboretum 71: 221-250.

Al-Shehbaz IA. 2004. A synopsis of the South American Weberbauera (Brassicaceae). Novon 14: 258-268.
Al-Shehbaz IA. 2012. A generic and tribal synopsis of the Brassicaceae (Cruciferae). Taxon 61: 931-954.

Al-Shehbaz IA. 2017. Englerocharis cuzcoensis (Brassicaceae), a new species from Peru and a synopsis of Englerocharis. Novon 25: 399-403.

Al-Shehbaz IA, Cano A, Manchego MAC, Salariato DL. 2018. Remarkable discoveries in the long-neglected and Peruvian-endemic genus Machaerophorus (Brassicaceae). Phytotaxa 360: 114-124.

Ané C, Larget B, Baum DA, Smith SD, Rokas A. 2007. Bayesian estimation of concordance among gene trees. Molecular Biology and Evolution 24: 412-426.

Antonelli A, Kissling WD, Flantua SG, Bermúdez MA, Mulch A, Muellner-Riehl AN, Kreft H, Linder HP, Badgley C, Fjeldså J, Fritz SA, Rahbek C, Herman F, Hooghiemstra H, Hoorn C. 2018. Geological and climatic influences on mountain biodiversity. Nature Geoscience 11: 718-725.

Appel O, Al-Shehbaz IA. 2003. Cruciferae. In: Kubitzki K, Bayer C, eds. The families and genera of vascular plants, Vol. 5. Berlin: Springer-Verlag, 75-174.

Barraclough TG, Vogler AP. 2000. Detecting the geographical pattern of speciation from species-level phylogenies. The American Naturalist 155: 419-434.

Barthlott W, Mutke J, Rafiqpoor MD, Kier G, Kref H. 2005. Global centres of vascular plant diversity. Nova Acta Leopoldina 92: 61-83.

Baum DA. 2007. Concordance trees, concordance factors, and the exploration of reticulate genealogy. Taxon 56: 417-426.

Beilstein MA, Al-Shehbaz IA, Kellogg EA. 2006. Brassicaceae phylogeny and trichome evolution. American Journal of Botany 93: 607-619.

Beilstein MA, Al-Shehbaz IA, Mathews S, Kellogg EA. 2008. Brassicaceae phylogeny inferred from phytochrome A and $n d h F$ sequence data: tribes and trichomes revisited. American Journal of Botany 95: 1307-1327.

Bellard C, Bertelsmeier C, Leadley P, Thuiller W, Courchamp F. 2012. Impacts of climate change on the future of biodiversity. Ecology Letters 15: 365-377.

Bivand R, Lewin-Koh N. 2019. maptools: tools for handling spatial objects. $R$ package version $0.9-5$. https://CRAN.Rproject.org/package $=$ maptools

Bivand RS, Pebesma E, Gomez-Rubio V. 2013. Applied spatial data analysis with $R, 2$ nd edn. New York: Springer.

Broennimann O, Di Cola V, Guisan A. 2018. ecospat: spatial ecology miscellaneous methods. $R$ package version 3.0. Available at: https://CRAN.R-project.org/package=ecospat Accessed March 2019

Broennimann O, Fitzpatrick MC, Pearman PB, Petitpierre B, Pellissier L, Yoccoz NG, Thuiller W, Fortin M, Randin C, Zimmermann NE, Graham CH, Guisan A. 2012. Measuring ecological niche overlap from occurrence and spatial environmental data. Global Ecology and Biogeography 21: 481-497.

Cabrera AL, Willink A. 1973. Biogeografía de América Latina. Washington: Monografías OEA.

Calenge C. 2006. The package adehabitat for the $R$ software: a tool for the analysis of space and habitat use by animals. Ecological Modelling 197: 516-519. 
Cuesta F, Muriel P, Llambí LD, Halloy S, Aguirre N, Beck S, Carilla J, Meneses RI, Cuello S, Grau A, Gámez LE, Irazábal J, Jácome J, Jaramillo R, Ramírez L, Samaniego N, Suárez-Duque D, Thompson $\mathbf{N}$, Tupayachi A, Viñas P, Yager K, Becerra MT, Pauli H, Gosling WD. 2017. Latitudinal and altitudinal patterns of plant community diversity on mountain summits across the tropical Andes. Ecography 40: 1381-1394.

Darriba D, Taboada GL, Doallo R, Posada D. 2012. jModelTest2: More models, new heuristics and parallel computing. Nature Methods 9: 772 .

Dawson TP, Jackson ST, House JI, Prentice IC, Mace GM. 2011. Beyond predictions: biodiversity conservation in a changing climate. Science 332: 53-58.

Di Cola V, Broennimann O, Petitpierre B, Breiner FT, D'Amen M, Randin C, Engler R, Pottier J, Pio D, Dubuis A, Pellissier L, Mateo RG, Hordijk W, Salamin N, Guisan A. 2017. Ecospat: an R package to support spatial analyses and modeling of species niches and distributions. Ecography 40: 774-787.

Downs JA, Horner MW. 2009. A characteristic-hull based method for home range estimation. Transactions in GIS 13: 527-537.

Drummond AJ, Suchard MA, Xie D, Rambaut A. 2012. Bayesian phylogenetics with BEAUti and the BEAST 1.7. Molecular Biology and Evolution 29: 1969-1973.

Edgar RC. 2004. MUSCLE: Multiple sequence alignment with high accuracy and high throughput. Nucleic Acids Research 32: 1792-1797.

Grummer JA, Bryson RW, Reeder TW. 2014. Species delimitation using Bayes factors: simulations and application to the Sceloporus scalaris species group (Squamata: Phrynosomatidae). Systematic Biology 6: 119-133.

Hall TA. 1999. BioEdit: a user-friendly biological sequence alignment editor and analysis program for Windows 95/98/ NT. Nucleic Acids Symposium Series 41: 95-98.

Halloy SR, Mark AF. 2003. Climate-change effects on alpine plant biodiversity: a New Zealand perspective on quantifying the threat. Arctic, Antarctic, and Alpine Research 35: 248-254.

Heibl C, Calenge C. 2018. phyloclim: integrating phylogenetics and climatic niche modeling. $R$ package version 0.9.5. Available at: https://CRAN.R-project.org/package=phyloclim. Accessed March 2019.

Heled J, Drummond AJ. 2010. Bayesian inference of species trees from multilocus data. Molecular Biology and Evolution 27: 570-580.

Hijmans RJ. 2019. raster: geographic data analysis and modeling. $R$ package version 2.8-19. Available at: https://CRAN.R-project. org/package=raster. Accessed March 2019.

Huang CH, Sun R, Hu Y, Zeng L, Zhang N, Cai L, Zhang Q, Koch MA, Al-Shehbaz IA, Edgar PP, Pires JC, Tan DY, Zhong Y, Ma H. 2016. Resolution of Brassicaceae phylogeny using nuclear genes uncovers nested radiations and supports convergent morphological evolution. Molecular Biology and Evolution 33: 394-412.

Huson DH, Bryant D. 2006. Application of phylogenetic networks in evolutionary studies. Molecular Biology and Evolution 23: 254-267.
Huson DH, Dezulian T, Klopper T, Steel MA. 2004. Phylogenetic super-networks from partial trees. IEEE / ACM Transactions on Computational Biology and Bioinformatics 1: 151-158.

IUCN Standards and Petitions Subcommittee. 2017. Guidelines for using the IUCN Red List categories and criteria. Version 13. Available at: http://www.iucnredlist.org/ documents/RedListGuidelines.pdf. Accessed April 2019.

Karger DN, Conrad O, Böhner J, Kawohl T, Kreft H, Soria-Auza RW, Zimmermann NE, Kessler M. 2017a. Climatologies at high resolution for the earth's land surface areas. Scientific Data 4: 170122.

Karger DN, Conrad O, Böhner J, Kawohl T, Kreft H, Soria-Auza RW, Zimmermann NE, Linder HP, Kessler M. 2017b. Data from: climatologies at high resolution for the earth's land surface areas. Dryad Digital Repository. doi:10.5061/dryad.kd1d4.

Kass RE, Raftery AE. 1995. Bayes factors. Journal of the American Statistical Association 90: 773-795.

Larget BR, Kotha SK, Dewey CN, Ané C. 2010. BUCKy: gene tree/species tree reconciliation with Bayesian concordance analysis. Bioinformatics 26: 2910-2911.

Lartillot N, Philippe H. 2006. Computing Bayes factors using thermodynamic integration. Systematic Biology 55: 195-207.

Liu C, Berry PM, Dawson TP, Pearson RG. 2005. Selecting thresholds of occurrence in the prediction of species distributions. Ecography 28: 385-393.

Liu C, White M, Newell G. 2013. Selecting thresholds for the prediction of species occurrence with presence-only data. Journal of Biogeography 40: 778-789.

Losos JB, Glor RE. 2003. Phylogenetic comparative methods and the geography of speciation. Trends in Ecology and Evolution 18: 220-227.

Luebert F, Weigend M. 2014. Phylogenetic insights into Andean plant diversification. Frontiers in Ecology and Evolution 2: 27.

Macbride JF. 1938. Cruciferae. Flora de Peru. Field Museum of Natural History. Botanical series 13: 937-983.

Mantyka-Pringle CS, Visconti P, Di Marco M, Martin TG, Rondinini C, Rhodes JR. 2015. Climate change modifies risk of global biodiversity loss due to land-cover change. Biological Conservation 187: 103-111.

Miller MA, Pfeiffer W, Schwartz T. 2010. Creating the CIPRES Science Gateway for inference of large phylogenetic trees. In: Proceedings of the Gateway Computing Environments Workshop (GCE). New Orleans: IEEE, 1-8.

Moritz C. 1994. Defining 'evolutionarily significant units' for conservation. Trends in Ecology and Evolution 9: 373-375.

Morrone JJ. 2001. Biogeografía de América Latina y el Caribe, Vol. 3. Zaragoza: Manuales and Tesis SEA.

Myers N, Mittermeier RA, Mittermeier CG, Da Fonseca GA, Kent J. 2000. Biodiversity hotspots for conservation priorities. Nature 403: 853-858.

Nikolov LA, Shushkov P, Nevado B, Gan X, Al-Shehbaz IA, Filatov D, Bailey CD, Tsiantis M. 2019. Resolving the backbone of the Brassicaceae phylogeny for investigating trait diversity. New Phytologist 222: 1638-1651.

Olson DM, Dinerstein E, Wikramanayake ED, Burgess ND, Powell GVN, Underwood EC, D’Amico JA, Itoua 
I, Strand HE, Morrison JC, Loucks CJ, Allnutt TF, Ricketts TH, Kura Y, Lamoreux JF, Wettengel WW, Hedao P, Kassem KR 2001. Terrestrial ecoregions of the world: a new map of life on Earth. BioScience 51: 933-938.

Perrigo A, Hoorn C, Antonelli A. 2019. Why mountains matter for biodiversity. PeerJ Preprints 7: e27768v1

Phillips SJ, Anderson RP, Dudík M, Schapire RE, Blair ME. 2017. Opening the black box: an open-source release of Maxent. Ecography 40: 887-893.

Pyron RA, Costa GC, Patten MA, Burbrink FT. 2015. Phylogenetic niche conservatism and the evolutionary basis of ecological speciation. Biological Reviews 90: 1248-1262.

Quantum GIS Development Team. 2016. QGIS Geographic Information System. Open Source Geospatial Foundation. Available at: http://qgis.org

R Core Team. 2018. $R$ : a language and environment for statistical computing. Vienna: R Foundation for Statistical Computing. Available at: https://www.R-project.org. Accessed April 2019.

Rambaut A, Drummond AJ, Xie D, Baele G, Suchard MA. 2018. Posterior summarization in Bayesian phylogenetics using Tracer 1.7. Systematic Biology 67: 901-904.

Rollins RC, Banerjee U. 1976. Trichomes in studies of the Cruciferae. In: Vaughan JG, MacLeod AJ, Jones BMG, eds. The biology and chemistry of the Cruciferae. London: Academic Press: 145-166.

Ronquist F, Teslenko M, van der Mark P, Ayres DL, Darling A, Höhna S, Larget B, Liu L, Suchard MA, Huelsenbeck JP. 2012. MrBayes 3.2: efficient Bayesian phylogenetic inference and model choice across a large model space. Systematic Biology 61: 539-542.

Salariato DL. 2019. Data from "Molecular data reveal hidden diversity within the central Andean species Weberbauera spathulifolia (Thelypodieae: Brassicaceae)". figshare doi: 10.6084/m9.figshare.11443407.v1.

Salariato DL, Al-Shehbaz IA. 2014. Zuloagocardamum (Brassicaceae: Thelypodieae) a new genus from the Andes highlands of northern Argentina. Systematic Botany 39: 563-577.

Salariato DL, Al-Shehbaz IA, Zuloaga FO. 2018. Reinstatement of the southern Andean genus Stenodraba (Brassicaceae) based on molecular data and insights from its environmental and geographic distribution. Systematic Botany 43: 35-52.

Salariato DL, Zuloaga FO. 2017. Climatic niche evolution in the Andean genus Menonvillea (Cremolobeae: Brassicaceae). Organisms Diversity and Evolution 17: 11-28.

Salariato DL, Zuloaga FO, Al-Shehbaz IA. 2013. Revision and tribal placement of the Argentinean genus Parodiodoxa (Brassicaceae). Plant Systematics and Evolution 299: 305-316.

Salariato DL, Zuloaga FO, Al-Shehbaz IA. 2019. Pennellia yalaensis (Brassicaceae: Halimolobeae), a new species from the Andes of northern Argentina. Systematic Botany 44: 355-368.

Salariato DL, Zuloaga FO, Cano A, Al-Shehbaz IA. 2015. Molecular phylogenetics of tribe Eudemeae (Brassicaceae) and implications for its morphology and distribution. Molecular Phylogenetics and Evolution 82: 43-59.

Salariato DL, Zuloaga FO, Franzke A, Mummenhoff K, Al-Shehbaz IA. 2016. Diversification patterns in the
CES clade (Brassicaceae tribes Cremolobeae, Eudemeae, Schizopetaleae) in Andean South America. Botanical Journal of the Linnean Society 181: 543-566.

Schoener TW. 1970. Nonsynchronous spatial overlap of lizards in patchy habitats. Ecology 51: 408-418.

Shimodaira H. 2002. An approximately unbiased test of phylogenetic tree selection. Systematic Biology 51: 492-508.

Shimodaira H, Hasegawa M. 1999. Multiple comparisons of loglikelihoods with applications to phylogenetic inference. Molecular Biology and Evolution 16: 1114-1116.

Shimodaira H, Hasegawa M. 2001. CONSEL: for assessing the confidence of phylogenetic tree selection. Bioinformatics 17: $1246-1247$.

Sklenář P, Balslev H. 2005. Superpáramo plant species diversity and phytogeography in Ecuador. Flora - Morphology, Distribution, Functional Ecology of Plants 200: 416-433.

Stamatakis A. 2014. RAxML version 8: a tool for phylogenetic analysis and post-analysis of large phylogenies. Bioinformatics 30: 1312-1313.

Stamatakis A, Hoover P, Rougemont J. 2008. A rapid bootstrap algorithm for the RAxML web-servers. Systematic Biology 57: 758-771.

Swofford DL. 2002. PAUP*: phylogenetic analysis using parsimony (*and other methods), v. 4.0 beta 10. Sunderland: Sinauer Associates.

Thiers B. 2019. [continuously updated]. Index herbariorum: a global directory of public herbaria and associated staff. The Bronx: New York Botanical Garden's Virtual Herbarium. Available at: http://sweetgum.nybg.org/science/ih/. Accessed May 2019.

Trabucco A, Zomer R. 2019. Global aridity index and potential evapotranspiration (ETO) climate database v2. figshare Dataset doi: 10.6084/m9.figshare.7504448.v3.

Turland NJ, Wiersema JH, Barrie FR, Greuter W, Hawksworth DL, Herendeen PS, Knapp S, Kusber WH, Li DZ, Marhold K, May TW, McNeill J, Monro AM, Prado J, Price MJ, Smith GF. 2018. International code of nomenclature for algae, fungi, and plants (Shenzhen Code) Glashütten: Koeltz Botanical Books. doi: 10.12705/Code.2018.

Urban MC. 2015. Accelerating extinction risk from climate change. Science 348: 571-573.

Warren DL, Glor RE, Turelli M. 2008. Environmental niche equivalency versus conservatism: quantitative approaches to niche evolution. Evolution 62: 2868-2883.

Warwick SI, Sauder CA, Mayer MS, Al-Shehbaz IA. 2009. Phylogenetic relationships in the tribes Schizopetaleae and Thelypodieae (Brassicaceae) based on nuclear ribosomal ITS region and chloroplast $n d h F$ DNA sequences. Botany 87: 961-985.

Weddell HA. 1864. Plantes inédites des Andes. Annales des Sciences Naturelles, Botanique 5: 283-291.

Wiens JJ. 2004. Speciation and ecology revisited: phylogenetic niche conservatism and the origin of species. Evolution 58: 193-197.

Wiens JJ, Graham CH. 2005. Niche conservatism: integrating evolution, ecology, and conservation biology. Annual Review of Ecology, Evolution, and Systematics 36: 519-539.

Xie W, Lewis PO, Fan Y, Kuo L, Chen MH. 2011. Improving marginal likelihood estimation for Bayesian phylogenetic model selection. Systematic Biology 60: 150-160. 


\section{SUPPORTING INFORMATION}

Additional Supporting Information may be found in the online version of this article at the publisher's web-site:

Table S1. Specimen occurrence data of Weberbauera spathulifolia used in the niche analyses and geographicalrange comparisons.

Table S2. Features of the DNA alignments used in the phylogenetic analyses within tribe Thelypodieae.

Table S3. Morphological and geographical comparison between specimens from the northern group (NG) (=Weberbauera spathulifolia) and the southern-central group (SCG) (=Weberbauera orophila). For morphological comparison characters were analysed on 32 and 55 specimens of the NG and SCG, respectively. Range/mean/ standard deviation are shown for quantitative characters. For geographical comparisons were studied 41 and 61 specimens of the NG and SCG, respectively. Complete vouchers are given in the Taxonomic Treatment section.

Table S4. Loadings on the first three components obtained from the principal component analysis (PCA-env) using bioclimatic variables extracted from the study area.

Table S5. Number of occurrences (n), area under the receiver operating characteristic curve (AUC), variable contribution (\%), permutation importance (\%) and jackknife test obtained in the Maxent modelling for each group within Weberbauera spathulifolia (NG and SCG).

Figure S1. Distribution map of Weberbauera spathulifolia and delimited area corresponding to the 50-km-buffered minimum convex polygon used in the niche analyses both along the environmental (E) and geographical $(\mathrm{G})$ space. Red and blue dots represent specimens of the northern group (NG) and the southern-central group (SCG) of Weberbauera, respectively.

Figure S2. Maximum likelihood trees generated with RAxML v.8.2.10 showing the phylogenetic placement of Weberbauera spathulifolia. Left, nrITS dataset. Rigth, cpDNA dataset (trnL-F/trnH-psbA). Values on branches correspond to bootstrap support $\geq 50 \%$. Units of branch length are proportional to nucleotide substitutions per site. NG: northern group of W. spathulifolia, SCG: southern-central group of W. spathulifolia.

Figure S3. Maximum likelihood tree generated with RAxML v.8.2.10 and the concatenated ITS+cpDNA ( $\operatorname{trnL}-F$ / trnH-psbA) dataset showing the phylogenetic placement of Weberbauera spathulifolia. Values on branches correspond to bootstrap support values $\geq 50 \%$. Units of branch length are proportional to nucleotide substitutions per site. NG: northern group of W. spathulifolia, SCG: southern-central group of W. spathulifolia.

Figure S4. Primary concordance tree from the BUCKy analyses using the 6002 trees from the ITS and the cpDNA datasets obtained in the MrBayes analyses and under $\alpha=1$. Concordance factor values $(\mathrm{CF}) \geq 0.5$ are shown on branches. Units of branch length are proportional to the concordance factor. Results from concordance analyses varying the discordance prior $(\alpha)$ had no effect on topology or concordance. NG, northern group of $W$. spathulifolia and SCG, southern-central group of W. spathulifolia.

Figure S5. Maximum clade credibility (MCC) species tree estimated from ITS and cpDNA datasets using the multispecies coalescent method implemented in *BEAST v.1.8.4 using all accessions as separate OTUs in the species tree in order to compare with results obtained from the concatenated analyses. Values on branches correspond to Bayesian posterior probability (\%). NG, northern group of W. spathulifolia; SCG, southern-central group of W. spathulifolia.

Figure S6. Results from the climatic-niche analyses in the space environmental (E) space obtained using the PCAenv method. Left, correlation circles showing the contribution of environmental variables on the first three axes of the PCA-env and the percentage of inertia explained. Right, PCA-env scatterplots of the first three principal components based on 21 climatic variables for the northern (NG) (blue dots) and southern-central (SCG) (red dots) groups of $W$. spathulifolia, represented by 41 and 61 occurrences, respectively. A, PC1 vs. PC2; B, PC1 vs. PC3 and C, PC2 vs. PC3.

Figure S7. Climatic niches for groups of Weberbauera spathulifolia produced by the three main axes of the PCA-env. For each group, the grey to black shading represents the grid cell density of the species occurrence (black being the highest density). The dashed line represents $50 \%$ of the available environment and the solid line represents $100 \%$.

Figure S8. Analyses in the geographical $(G)$ space. A, values of variables (first five principal components of the PCA-env) used in the MaxEnt models for northern (NG) and southern-central (SCG) groups of Weberbauera spathulifolia along the study area. Blue and red dots represent specimen occurrences for NG and SCG, respectively. B, response curves for each PC used in the MaxEnt models of NG and SCG groups. Response curves show the ranges in environmental conditions that are more favourable for the distribution of each group. The $x$-axis of the variables represents their ranges for the complete study area, while the $y$-axis represents the predicted suitability of the focus variable when all of the other variables are set to their average. Red line represents the mean response while blue shaded area represents \pm 1 standard deviation.

File ITS.nex. ITS dataset used for phylogenetic analyses in this study. 
File trnLF.nex. $\operatorname{trn} L-F$ dataset used for phylogenetic analyses in this study.

File trnH.nex. $t r n H-p s b A$ dataset used for phylogenetic analyses in this study.

\section{APPENDIX 1}

Taxa and GenBank accession numbers for the ITS, $\operatorname{trn} L-F$ and $\operatorname{trn} H-p s b A$ sequences used in the phylogenetic analyses. For new sequences generated for this study (italic accession numbers) vouchers are provided.

Sisymbrium orientale L. (LC003518, DQ649092, KF973451)(OUTGROUP).Caulanthus crassicaulis (Torr.) S.Watson (EU620267, EU620341, KF973418). Caulanthus heterophyllus (Nutt.) Payson (EU620268, EU620342, KF973420).Chilocardamum castellanosii (O.E.Schulz) Al-Shehbaz (1): (AY958592, AY958548, -); (2): F. O. Zuloaga 15091 (SI), Argentina, Neuquén (MN836388, MN836430, MN836487). Chilocardamum patagonicum (Speg.) O.E.Schulz: F. O. Zuloaga 14102 (SI), Argentina, Santa Cruz (KF569758, KF569761, MN836478). Chlorocrambe hastata (S. Watson) Rydb. (EU620269, EU620346, -). Dictyophragmus punensis (Romanczuk) Al-Shehbaz: (1) (EU620294, EU620349, -); (2): F. O. Zuloaga 14221 (SI), Argentina, Jujuy (MN836386, MN836428, MN836485). Dryopetalon auriculatum (A.Gray) Al-Shehbaz (EU620290,EU620347,-).Englerocharis pauciflora Al-Shehbaz (EU620351, EU620295, - ). Hesperidanthus barnebyi (S.L. Welsh \& N.D. Atwood) Al-Shehbaz (EU620271, EU620356, -). Hesperidanthus jaegeri (Rollins) Al-Shehbaz (EU620272+EU620257, EU620357, - ). Mostacillastrum andinum (Phil.) Al-Shehbaz (1): (AF531649, EU620363, -); (2): F. O. Zuloaga 15218 (SI), Argentina, Mendoza (MN836391, MN836433, MN836489). Mostacillastrum commune (Speg.) Al-Shehbaz (1): (AY958593, AY958549, -); (2): F. O. Zuloaga 15090 (SI), Argentina, Neuquén (MN836392, MN836434, MN836490). Mostacillastrum gracile (Wedd.) Al-Shehbaz (AY958596, AY958554, -). Mostacillastrum leptocarpum (Hook. \& Arn.) Al-Shehbaz (1): (AF531632, AY958556, -); (2): F. O. Zuloaga 15286 (SI), Argentina, Mendoza (MN836390, MN836432, MN836488). Mostacillastrum orbignyanum (E.Fourn.) Al-Shehbaz (1): (AF531583, AY958537, -); (2): F. O. Zuloaga 14968 (SI), Argentina, La Rioja (MN836389, MN836431,-).Mostacillastrum stenophyllum (Gilles ex Hook. \& Arn.) O.E.Schulz (EU620305, EU620364,-). Mostacillastrum volckmannii (Phil.) D.A.German \& Al-Shehbaz (AF531599, AY958564, -). Neuontobotrys frutescens (Gillies ex Hook. \& Arn.) Al-Shehbaz (1): (AY958595, AY958551, -); (2): F. O. Zuloaga 14961 (SI), Argentina, La Rioja (MN836387, MN836429, MN836486).
Neuontobotrys lanata (Walp.) Al-Shehbaz (AF531651, EU620365, -). Neuontobotrys linearifolius (Kuntze) Al-Shehbaz (EU620306, EU620367, -). Neuontobotrys robusta (Chodat \& Wilczek) Al-Shehbaz: F. O. Zuloaga 12396 (SI), Argentina, Mendoza (MN836385, MN836427, MN836484). Neuontobotrys tarapacana (Phil.) Al-Shehbaz (KC174372, EU620368, -). Parodiodoxa chionophila (Speg.) O.E.Schulz: G. E. Barboza 2566 (CORD), Argentina, La Rioja (JX971121, JX971122, MN836476). Polypsecadium adscendens (O.E.Schulz) Al-Shehbaz (EU620308, AY958544, -). Polypsecadium arnottianum (Gillies ex Hook. \& Arn.) Al-Shehbaz (1): (AF531629, EU620369, -); (2): F. O. Zuloaga 15313 (SI), Argentina, Mendoza (MN836395,MN836437,MN836493).Polypsecadium gilliesii (Romanczuk) Al-Shehbaz: C. Zanotti 867 (SI), Argentina, Tucumán (MN836397, MN836439, MN836495). Polypsecadium grandiflorum Romanczuk \& Boelcke (1): (EU620309, EU620370, -); (2): C. Zanotti 655 (SI), Argentina, Jujuy (MN836396, MN836438, MN836494). Polypsecadium harmsianum (Muschl.) O.E.Schulz (1): (EU620310, EU620371, -); (2): F. O. Zuloaga 13465 (SI), Argentina, Jujuy (MN836394, MN836436, MN836492). Polypsecadium magellanicum (Juss. ex Pers.) Al-Shehbaz (1): (AF531589, AY958558, -); (2): F. O. Zuloaga 14071 (SI), Argentina, Santa Cruz (MN836383,MN836425,MN836477).Polypsecadium rusbyi (Britton) Al-Shehbaz (AF531597, EU620372, -). Polypsecadium solidagineum (Triana \& Planch.) Al-Shehbaz (AF531602, EU620373, -). Romanschulzia arabiformis (DC.) Rollins (AF531635, AY958538, -). Romanschulzia costaricensis (Standl.) Rollins (AF531636,AY958539, -). Sarcodraba karraikensis (Speg.) Gilg \& Muschl.: F. O. Zuloaga 13972 (SI), Argentina, Santa Cruz (MN836384, MN836426, MN836483). Sibara anethifolia (Phil.) Al-Shehbaz: M. Muñoz 4678 (MO), Chile, Atacama (MH998027, MH998037, MN836499). Sibara angelorum (S. Watson) Greene (1): (EU620317, EU620379, -); (2): D. E. Breedlove \& C. Burns 71844 (MO), Mexico, Baja California (MH998028, -, MN836497). Sibara deserti (M.E.Jones) Rollins: R. Rollins \& P. A. Munz 6748 (MO), United States, California (MH998029, -, MN836496). Sibara filifolia (Greene) Greene (MH998030, -, -). Sibara laxa (S.Watson) Greene (1): (AF53163, AY958543, -); (2): D. E. Breedlove \& C. Burns 71846 (MO), Mexico, Baja California (MH998031, MH998038, MN836498). Sibara 
macrostachya (Phil.) Al-Shehbaz (1): (EU620337, EU620403, -); (2): Billiet \& Jadin 5561 (MO), Chile, Antofagasta (MH998032, -, MN836500). Sibara mendocina (Boelcke \& Arroyo-Leuenb.) Al-Shehbaz (EU620338, EU620404, -). Sibara tehuelches (Speg.) Al-Shehbaz (1): (EU620311, EU620374, -); (2): F. O. Zuloaga 13963 (SI), Argentina, Chubut (MH998033, MH998039, MN836480). Sibaropsis hammittii S.Boyd \& T.S.Ross (EU620318, EU620380, KF973417). Stanleya pinnata (Pursh) Britton: (EU620319, EU620381, KF973416). Streptanthella longirostris (S.Watson) Rydb. (EU620320, EU620383, KF973447). Streptanthus cordatus Nutt. (EU620322, EU620384,KF973431).Streptanthus hyacinthoides Hook. (EU620276, EU620385, -). Streptanthus maculatus Nutt. (EU620326, EU620386, KF973426). Thelypodiopsis ambigua (S. Watson) Al-Shehbaz (EU620278, EU620389, -). Warea amplexifolia (Nutt.) Nutt. (EU620280+EU620265, EU620397, -). Warea cuneifolia (Muhl. ex Nutt.) Nutt. (EU620281+EU620266, EU620398, -). Weberbauera arequipa Al-Shehbaz \& Montesinos: D. Montesinos 3842 (MO), Perú, Moquegua (MF806388, MF806421, MN836501). Weberbauera ayacuchoensis Al-Shehbaz, A.Cano \& Trinidad (1): A. Cano 19557 (MO), Perú, Arequipa (-, MN836440, MN836502); (2): A. Cano 20641 (USM), Perú, Arequipa (MN836415, MN836461, MN836524). Weberbauera cymosa Al-Shehbaz (1): H. Trinidad 1911 (MO), Perú, Junín (MF806389, MF806422, MN836503); (2): S. G. Beck 21752 (LPB), Bolivia, La Paz (MN836416, MN836462, MN836525). Weberbauera densifolia Al-Shehbaz (1): F. O. Zuloaga 13540 (SI), Argentina, Jujuy (MN836400, MN836446, MN836509); (2): F. M. Rodrigues 1360 (BA), Argentina, Catamarca (-, MN836464, MN836527). Weberbauera herzogii (O.E.Schulz) Al-Shehbaz (1): (EU620334, EU620400, -); (2): F. O. Zuloaga 14344 (SI), Argentina, Jujuy (MF806384, MF806417, MN836481); (3): F. O. Zuloaga 13490 (SI), Argentina, Jujuy (MN836398, MN836444, MN836507); (4): D. L. Salariato \& A. Lliully Aguilar 34 (SI), Bolivia, La Paz (MN836404, MN836450, MN836513); (5): F. O. Zuloaga 15975 (SI), Argentina, Salta (MN836414, MN836460, MN836523); (6): $H$. Pestalozzi 829 (LPB), Bolivia, Cochabamba (MN836419, MN836466, -); (7): S. G. Beck 35014 (LPB), Bolivia, La Paz (MN836420, MN836467, MN836528); (8): F. O. Zuloaga 16301 (SI), Argentina, Jujuy (MN836424, MN836474, MN836535). Weberbauera peruviana (DC.) Al-Shehbaz (1): (EU620335, EU620401, -); (2): F. O. Zuloaga 13553 (SI), Argentina, Jujuy (MF806385, MF806418, MN836482); (3): D. L. Salariato \& A. Lliully Aguilar 26 (SI), Bolivia, La Paz
(MN836403, MN836449, MN836512); (4): D. L. Salariato \& H. Trinidad 54 (SI), Peru, Anchash (MN836406, MN836452, MN836515); (5): F. O. Zuloaga 15881 (SI), Argentina, Salta (MN836413, MN836459, MN836522); (6): D. Montesinos 3711 (USM), Perú, Moquegua (MN836418, MN836465, -); (7): M. Vargas 496 (LPB), Bolivia, Cochabamba (MN836421, MN836469, MN836469); (8): Schultz 163 (LPB), Bolivia, Potosí (-, MN836468, MN836529); (9): P. Gonzáles 3555 (USM), Perú, Huancavelica (-, MN836471, MN836532). Weberbauera rosulans (O.E.Schulz) Al-Shehbaz (1): (EU620284, EU620340, -); (2): D. L. Salariato \& H. Trinidad 58 (SI), Perú, Ancash (MN836408, MN836454, MN836517); (3): M. I. Latorre 4159 (MO), Perú, Ancash (MF806390, MN836441, MN836504); (4): D. L. Salariato \& H. Trinidad 90 (SI), Perú, Ancash (MN836412, MN836458, MN836521). Weberbauera scabrifolia Al-Shehbaz: M. Weigend 5220 (MO), Perú, Huanuco (-, MN836442, MN836505). Weberbauera smithii Al-Shehbaz: D. L. Salariato \& H. Trinidad 81 (SI), Perú, Ancash (MN836410, MN836456, MN836519). Weberbauera spathulifolia (A.Gray) O.E.Schulz (1): D. L. Salariato \& H. Trinidad 56 (SI), Perú, Ancash (MN836407, MN836453, MN836516); (2): D. L. Salariato \& H. Trinidad 53 (SI), Perú, Ancash (MN836405, MN836451, MN836514); (3): M. I. Latorre 2725 (USM), Perú, Ancash (MN836422, MN836472, MN836533); (4): D. L. Salariato \& H. Trinidad 86 (SI), Perú, Ancash (MN836411, MN836457, MN836520); (5): D. L. Salariato \& A. Lliully Aguilar 21 (SI), Bolivia, La Paz (MN836402, MN836448, MN836511); (6): U. Fissel 188 (LPB), Bolivia, La Paz (-, MN836470, MN836531); (7): F. O. Zuloaga 16299 (SI), Argentina, Jujuy (MN836423, MN836473, MN836534); (8): F. O. Zuloaga 13561 (SI), Argentina, Jujuy (MN836393, MN836435, MN836491); (9): L. Salomón 241 (SI), Argentina, Catamarca (MN836401, MN836447, MN836510); (10): G. E. Barboza 2619 (CORD), Argentina, La Rioja (MF806423, MF806391, -); (11): G. E. Barboza 2583 (CORD), Argentina, La Rioja (-, MN836443, MN836506); (12): S. Donadío 122 (SI), Argentina, La $\mathrm{R}$ i o j a $\quad(M N 836399, \quad M N 836445$, MN836508).Weberbauera trichocarpa (Muschl.) J.F.Macbr. (1): D. L. Salariato \& H. Trinidad 70 (SI), Perú, Anchash (MN836409, MN836455, MN836518); (2): O. Tobar 9074 (USM), Perú, Junín (MN836417, MN836463, MN836526). Zuloagocardamum jujuyensis Salariato \& Al-Shehbaz (1): F. O. Zuloaga 13574 (SI), Argentina, Jujuy (KF569756, KF569759, MN836475); (2): F. O. Zuloaga 14267 (SI), Argentina, Jujuy (KF569757, KF569760, MN836479). 